\title{
Theranostics
}

Review

$2011 ; 1: 30-47$

\section{Why Integrin as a Primary Target for Imaging and Therapy}

\section{Gang Niu 1,2 and Xiaoyuan $\mathrm{Chen}^{2} \bowtie$}

1. Imaging Sciences Training Program, Radiology and Imaging Sciences, Clinical Center and National Institute Biomedical Imaging and Bioengineering, NIH

2. Laboratory of Molecular Imaging and Nanomedicine, National Institute of Biomedical Imaging and Bioengineering, National Institutes of Health, Bethesda, MD

Corresponding author: Dr. Xiaoyuan Chen, Laboratory of Molecular Imaging and Nanomedicine (LOMIN), National Institute of Biomedical Imaging and Bioengineering (NIBIB), National Institute of Health (NIH) , 31 Center Dr, 31/1C22, Bethesda, MD 20892, USA; Tel: 301-451-4246; Email: shawn.chen@nih.gov

(C) Ivyspring International Publisher. This is an open-access article distributed under the terms of the Creative Commons License (http://creativecommons.org/ licenses/by-nc-nd/3.0/). Reproduction is permitted for personal, noncommercial use, provided that the article is in whole, unmodified, and properly cited.

Published: 2011.01.16

\begin{abstract}
Integrin-mediated cell adhesion is involved in many essential normal cellular and pathological functions including cell survival, growth, differentiation, migration, inflammatory responses, platelet aggregation, tissue repair and tumor invasion. 24 different heterodimerized transmembrane integrin receptors are combined from 18 different $\alpha$ and 8 different $\beta$ subunits. Each integrin subunit contains a large extracellular domain, a single transmembrane domain and a usually short cytoplasmic domain. Integrins bind extracellular matrix (ECM) proteins through their large extracellular domain, and engage the cytoskeleton via their short cytoplasmic tails. These integrin-mediated linkages on either side of the plasma membrane are dynamically linked. Thus, integrins communicate over the plasma membrane in both directions, i.e., outside-in and inside-out signaling. In outside-in signaling through integrins, conformational changes of integrin induced by ligand binding on the extracellular domain altered the cytoplasmic domain structures to elicit various intracellular signaling pathways. Inside-out signaling originates from non-integrin cell surface receptors or cytoplasmic molecules and it activates signaling pathways inside the cells, ultimately resulting in the activation/deactivation of integrins. Integrins are one of key family proteins for cell adhesion regulation through binding to a large number of ECM molecules and cell membrane proteins. Lack of expression of integrins may result in a wide variety of effects ranging from blockage in pre-implantation to embryonic or perinatal lethality and developmental defects. Based on both the key role they played in angiogenesis, leukocytes function and tumor development and easy accessibility as cell surface receptors interacting with extracellular ligands, the integrin superfamily represents the best opportunity of targeting both antibodies and small-molecule antagonists for both therapeutic and diagnostic utility in various key diseases so far.
\end{abstract}

Key words: Integrin, inside-out signaling, outside-in signaling, cell adhesion molecule, angiogenesis.

\section{INTRODUCTION}

Adhesion of cells to the surrounding extracellular matrix (ECM) and to other cells is essential for tissue integrity, which have been crucial for the evolution from protozoans to metazoans. Integrin-mediated cell adhesion to ECM plays a central role in the formation and remodeling of tissues and organs in multicellular organisms [1-2]. Integrins mediate cell-to-cell and cell-to-ECM adhesion, providing adhesion for stationary cells, traction during cell movement and, importantly, the promotion of many 
signaling pathways that regulate diverse processes including proliferation, migration, cell survival, differentiation, tumor invasion and metastasis [3-4]. As a family of heterodimeric transmembrane receptors consisting of an $\alpha$ and a $\beta$ subunit, 18 different $\alpha$ and 8 different $\beta$ subunits are known in mammals, which can combine to 24 different integrin receptors [5-6]. Some subunits can combine with several different partners, adding to the structural complexity of integrin receptors. All these integrins can be segregated into two groups, one containing and the other lacking an extra von Willebrand factor type A domain (vWFA, known as aA or aI in integrins) in their a-subunits (Fig. 1). The composition and morphology of integrin-dependent adhesions (focal complexes/ podosomes, focal adhesions and fibrillar adhesions) vary with the cell type, matrix and integrin, and may switch from one adhesion contact to another, contributing to cell advancement, tissue remodeling and repair [7]. Based on their important biological and pathological function, integrins have been intensively investigated as imaging or therapy targets, which will be discussed in details in the following chapters of this book. The purpose of this chapter is to give an overall description of the structure, expression pattern, and biological/pathological function of various integrins.

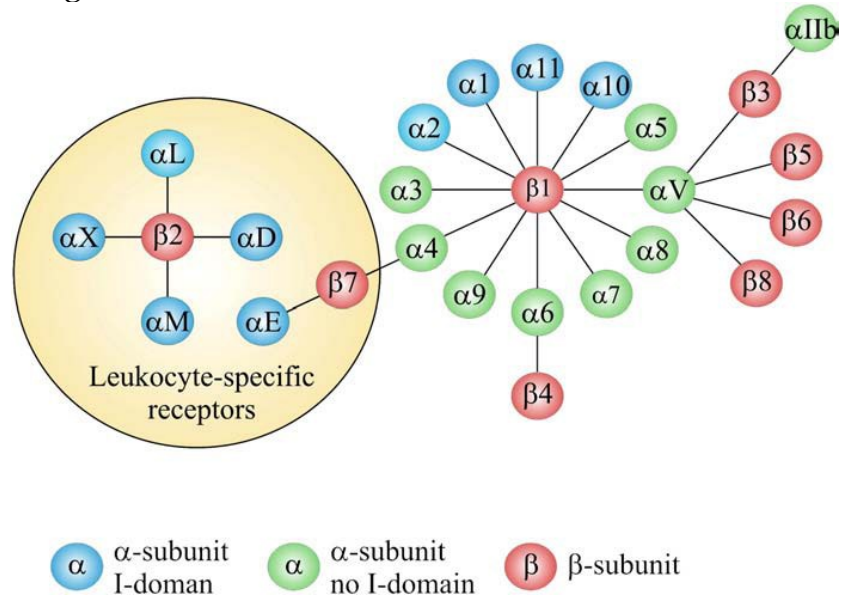

Figure I. The integrin superfamily. The integrins can be subdivided according to their $\beta$ chains but note that some $\alpha$ chains can combine with several $\beta$ chains. 24 different integrins are present in humans [8].

\section{INTEGRIN STRUCTURE}

Each integrin subunit contains a large extracellular domain (N-terminus of $>700$ residues), a single transmembrane domain ( $>20$ residues) and a usually short cytoplasmic domain (C-terminus of 13-70 residues) [9]. The I (inserted) domain is the most im- portant integrin domain in ligand recognition [10]. For integrins, the aI domain presents in approximately half of all a subunits and the $\beta \mathrm{I}$ domain presents in all $\beta$ subunits. The aI domain is the primary ligand binding region in the integrins which have this domain. Whereas in integrins which lack the a I domain, the binding site in the integrin "head" is formed by structural contributions of both the $\alpha$ and $\beta$ chains [11]. aI is a GTPase-like domain in which the catalytic site at the apex is replaced with a conserved metal-ion-dependent adhesion site (MIDAS), which is occupied by a divalent cation. All of the integrin-ligand interfaces analyzed thus far have had at their center a coordinate bond between the integrin MIDAS and a carboxylate from the ligand and $\mathrm{Mg}^{2+}$ is the physiological metal that comprises integrin MIDAS [12]. aI domains have been crystallized in three distinct conformations, termed closed, intermediate, and open, with coordination of the metal in the MIDAS, arrangement of the $\beta 6-\alpha 7$ loop, and axial disposition of the C-terminal a7-helix along the side of the I domain [13-14]. Change in coordination at the MIDAS of a I domains is coupled to backbone movements of loops that bear the coordinating residues to increase complementarities to ligands (Figure 2) [15].

In the a2 I domain-collagen triple helical peptide structure [16], the stiff collagen rod docks onto a shallow trench on top of the I domain, with MIDAS situated at the center, coordinated by a glutamate residue of collagen. Another major aI ligand class is comprised of cell surface molecule intercellular cell adhesion molecules (ICAMs). These are recognized by a $\beta 2$ class of integrins that are exclusively expressed on leukocytes. This interaction is crucial in enabling leukocyte migration into sites of inflammation. Based on the structure of the ICAM-3-aL I domain solved by Song et al. [17], and the important structural determinants for the interaction are distributed across a rigid scaffold composed of a $\beta$ sheet and a structurally constrained loop.

When present, aI domain is situated at the top of the heterodimer and forms clear protrusions [18-19], whereas the $\beta$ I domain folds together intimately with the $\beta$-propeller domain of the a subunit, constituting half of the large globular head [20]. The crystal structure of the ectodomain from the aI domain-lacking integrin, av $\beta 3$, was also determined in both unliganded (in the presence of $\mathrm{Ca}^{2+}$ or $\mathrm{Mn}^{2+}$ ) and ligand-bound states [11, 21]. As shown in Figure 3, av consists of four domains: an $\mathrm{N}$ terminal seven-bladed $\beta$-propeller, an Ig-like Thigh domain and two large $\beta$-sandwich domains, Calf- 1 and Calf- 2 . The $\beta$-subunit comprises an N-terminal cysteine-rich PSI 
(Plexin-Semaphorin-Integrin) domain in which an Ig-like "Hybrid" domain is inserted in its c-terminal loop (the Hybrid domain contains in turn an aA-like domain ( $\beta \mathrm{A}$ domain) inserted between its two $\beta$-sheets). PSI is followed by four EGF-like domains and a membrane proximal novel tail domain ( $\beta$-TD). The propeller and $\beta$ A domains assemble into a "head" structure, which accounts for formation of the $\alpha \beta$ heterodimer. The integrin head sits on top of an $\alpha$ and a $\beta$ "legs", formed respectively of the Thigh and Calf domains from the aV-subunit and the PSI, Hybrid, EGF1-4 and $\beta$ TD domains from the $\beta 3$-subunit [11].

The structure of liganded av $\beta 3$ ectodomain was determined after diffusing the high affinity cyclic pentapeptide, cilengitide, which contains the prototypical Arg-Gly-Asp (cRGD), into preformed integrin crystals in the presence of $5 \mathrm{mM} \mathrm{Mn}{ }^{2+}$. RGD inserts into a crevice between the propeller and $\beta$ A domains, with the residues $R$ and $D$ side chains exclusively contacting the propeller and $\beta$ A domains, respectively, and bringing these two domains closer together [21]. The activating inward movement of a1 helix and rearrangement of the F/a7 loop seen in liganded a I are also observed in liganded $\beta \mathrm{I}$, leading to similar although much less dramatic changes in the three surface loops coordinating MIDAS and the SDL loop. Metal coordination at ADMIDAS changes significantly, such that it no longer locks the a1 helix to the $\mathrm{F} / \mathrm{a} 7$ loop, allowing the activating movements in both. The inward movement of a1 carries ADMIDAS with it, moving it closer to MIDAS, thus helping stabilize the new metal ion at MIDAS [21]. a

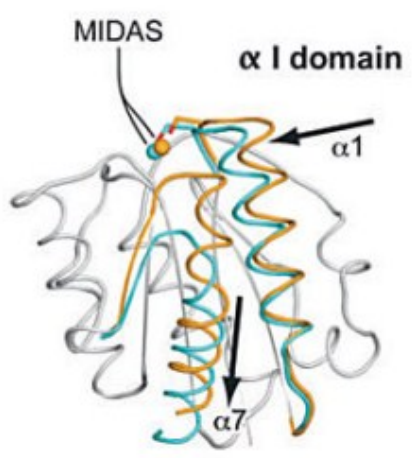

- Closed, low affinity

- Open, high affinity b

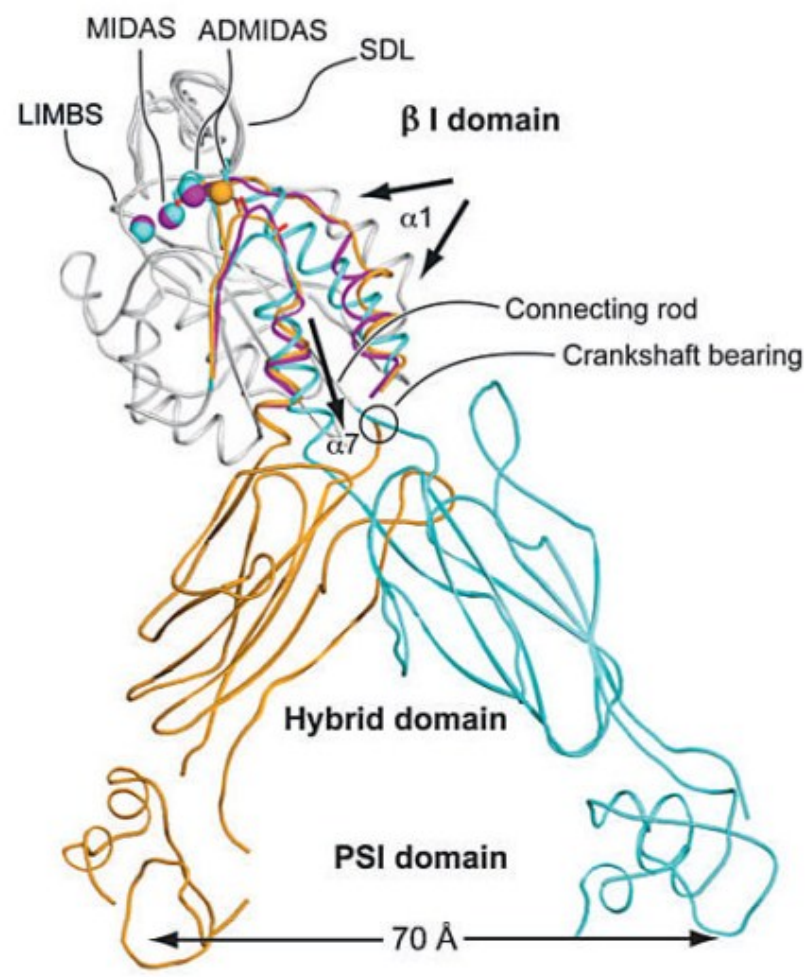

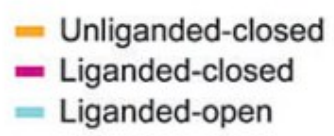

Figure 2. Conformational change and transmission of allostery by $\alpha$ and $\beta$ I domains. (a) The $\alpha$ I domain. Nonmoving segments of the backbone are shown as a gray worm. The moving segments of the backbone and the MIDAS metal ions are closed (gold) and open (cyan). The direction of movement is indicated with arrows. (b) The $\beta$ I domain and its linkage to the hybrid and plexin/semaphorin/integrin (PSI) domain. Nonmoving segments of the $\beta$ I backbone are shown as a gray worm. Moving segments and metal ions are color coded as shown. Directions of $\alpha \mathrm{l}$ - and $\alpha 7$-helix movements are shown with arrows [18]. 

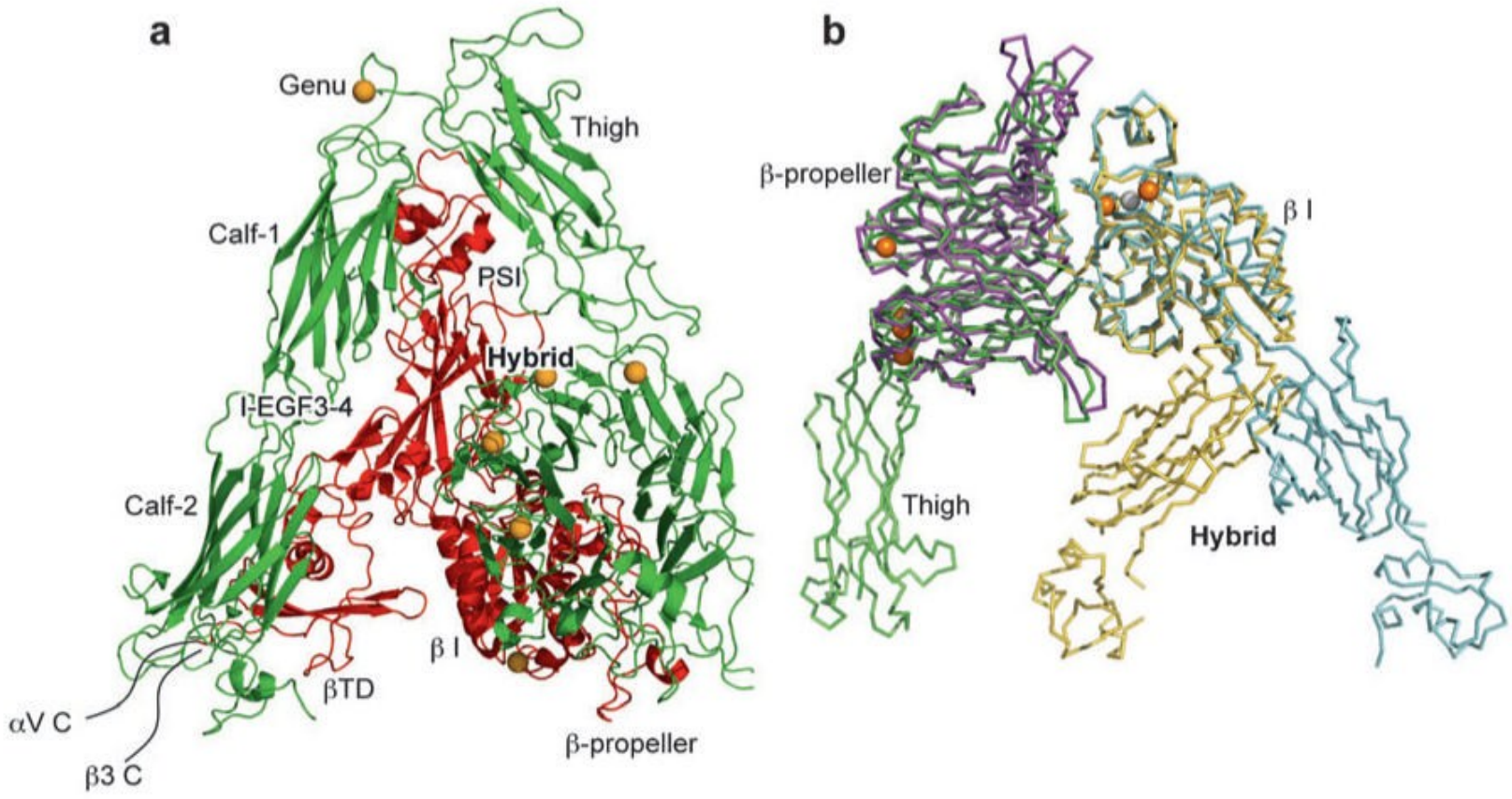

Figure 3. Crystal structures of integrins $\alpha \vee \beta 3$ and $\alpha$ llb $\beta 3$. (a) The structure of $\alpha \vee \beta 3$ in the bent conformation. The $\alpha \vee$ and $\beta 3$ subunits are colored in green and red, respectively. (b) Superposition of liganded-open allb $\beta 3$ and unliganded-closed $\alpha \mathrm{V} \beta 3$ headpieces. The $\alpha$ and $\beta$ subunits are colored in green and yellow in $\alpha \mathrm{V} \beta 3$ and in purple and light blue in $\alpha$ llb $\beta 3$. Calcium and magnesium ions in $\alpha$ llb $\beta 3$ only are gold and gray spheres, respectively [18].

Crystal structures of the $\operatorname{av} \beta 3$ ectodomain in complex with the cyclic RGD peptide [21], as well as another RGD-type integrin (aIIb $\beta 3$ ) complexed with ligand mimetic compounds [22] have revealed that the minimal RGD set provides two essential anchorpoints: one is the Asp carboxylate, which coordinates directly the $\beta$ MIDAS; the other is the Arg side chain (or basic moiety), which forms a salt bridge to an acidic residue in the b-propeller domain of the av/aIlb subunit. In addition, these anchorpoints are located at the bottom of the narrow cleft or 'well', where the small ligand compounds are well accommodated, burying more than half of the molecular surface at the interface. av $\beta 3$ integrin shows little preference in its choice among the many RGD-containing proteins. Surprisingly, even the strict RGD sequence requirement rule can be bent [23]. For example, cells from homozygous knock-in mice carrying the RGD $\rightarrow$ RGE mutation in fibronectin exhibited normal fibronectin assembly in an av 33 -dependent manner [24]. This observation indicated that the positioning of both an acidic and basic residue in proper geometrical proximity is sufficient for meaningful affinity. The well-type pocket containing $\beta$ MIDAS seems specifically designed to accommodate 'loop ligand'. Residues adjacent to RGD seem to provide some specificity toward certain in- tegrins, both by making extra direct contacts and by changing the 'width' of the RGD segment [25-26].

Although a MIDAS and $\beta$ MIDAS normally function in a tandem fashion in aI domain-containing integrins, they each could potentially engage two independent external ligands simultaneously. For example, semaphorin 7A, a GPI-anchored membrane protein that contains an RGD motif, was reported to promote axon outgrowth through b1 integrin(s), though the a subunit responsible for this activity was not determined [27]. Purified a1b1 does recognize semaphorin 7A in an RGD-dependent manner [28]. It is therefore tempting to speculate that RGD binds to the $\beta$ MIDAS, leaving the a MIDAS unoccupied. Laminins are major basement membrane proteins composed of three different polypeptide chains, termed $a, b$, and $g$. Till date, five $a$, three $b$, and three $g$ chains are known to make up at least 15 isoforms of heterotrimeric laminins in mammals [29]. It has been reported that integrins exhibited a distinct laminin isoform preference [30]. Mutational and antibody mapping studies have revealed that C-terminal laminin globular (LG) domains of the a chain, particularly LG1-3, are important for integrin recognition [31]. However, recombinant fragments corresponding to this region have not shown significant cell adhesion activity comparable to that of intact heterotrimeric 
laminins. Full integrin-binding activity of LG1-3 requires the heterotrimeric C-terminal portion of the coiled-coil domain, including the most distant C-terminal region of the $b$ and g chains [32].

Accumulating evidence supported that the structure changes of integrins are the basis of the integrin signaling. Indeed, negative stain electron microscopy with image averaging of integrins has shown three overall conformations of the extracellular domain and these correspond to a low affinity, bent conformation (as in the av $\beta 3$ structure), an intermediate affinity, extended form with a closed headpiece, and a high affinity, extended form with an open headpiece, which is induced by ligand mimetic compounds [22]. In integrins that lack the I-domain, the ligand binds directly to the $\beta$ I-like domain, and causes a downward movement of its a7 helix, similarly to what was described above for the integrin a I-domains. This shift results in a swing-out movement of the $\beta$ chain hybrid and PSI domains and these domains act as a rigid lever that transmits and amplifies the motion, resulting in a separation of the $a$ and $\beta$ legs and integrin extension [22]. On the other hand, the swing-out movement of the upper $\beta$ leg could readily occur if it were preceded by extension of both legs.

Several models have been proposed to integrate the structural changes of integrins and consequent biochemical findings [33]. For example, a "switchblade" model proposed that the head structure with the large $\left(\sim 80^{\circ}\right)$ Hybrid swing-out represents the high affinity state of $\beta$ A. To provide the necessary space for the Hybrid swing-out, the model suggests that the integrin first fully extend its knees, converting the bent into a linear asymmetric conformation, described as such in 2D EM images [19]. An alternate "deadbolt" model suggest that elastic deformation of the $\mathrm{F} / \mathrm{a} 7$ loop is possible with only modest quaternary changes at the $\beta$ TD interface with $\beta \mathrm{A}$ and possibly Hybrid domains [34]. It has been found that upon binding of ICAM-5 to the LFA-1 I-domain, a remarkable outward movement of the a7 helix was observed, which resulted in the replacement of the corresponding $\alpha 7$ helix from a neighboring I-domain into the $\alpha 7$ helix position, but in an upside-down configuration. This a7 helix replacement was further propagated, resulting in a large I-domain/ICAM-5 cluster. In this way, a weak initial interaction between the integrin and a ligand can result in the formation of large ligand/receptor aggregates [35].

\section{INTEGRIN SIGNALING}

Integrins bind ECM proteins through their large extracellular domain, and engage the cytoskeleton via their short cytoplasmic tails. These integrin-mediated linkages on either side of the plasma membrane are dynamically linked. The cytoskeleton controls affinity and avidity of the integrin extracellular domain to modulate the ECM, and integrin binding to ECM changes the shape and composition of the cytoskeleton beneath [36]. Thus, integrins communicate over the plasma membrane in both directions, i.e., outside-in and inside-out signaling [18]. In outside-in signaling through integrins, ligands bind to extracellular integrin domains, where a conformational change occurs so that the signal is transmitted into the cell. Integrin clustering may also occur. Inside-out signaling originates from non-integrin cell surface receptors or cytoplasmic molecules and it activates signaling pathways inside the cells, ultimately resulting in the activation/deactivation of integrins. In this case, adhesion may be regulated both by conformational changes in the integrin and by valency change (integrin clustering). In fact, both signaling events may occur simultaneously and reinforce each other [8].

Changes in interactions and/or in the structures of the cytoplasmic domains of integrins within the membrane-proximal regions play crucial roles in integrin activation via inside-out signaling [37-38]. Conformational changes of integrin induced by ligand binding on the extracellular domain altered the cytoplasmic domain structures to elicit various intracellular signaling pathways. A prominent biochemical event in integrin outside-in signaling is protein tyrosine phosphorylation due to activation of Src and FAK family protein tyrosine kinases [39-40]. Src and its inhibitory Csk are constitutively bound to the integrin $\beta$-tails. Integrin binding to ligand induces Src activation through Csk dissociation, Src transphosphorylation and/or recruitment of tyrosine phosphatases (e.g receptor tyrosine phosphatase RPTPa, or PTP-1B [39]. However, the spatiotemporal and structural basis of the interaction of integrin cytoplasmic-tails with the growing list of signaling molecules including cytosolic and receptor kinases (Src, FAK, Syk, ILK and PKC) and phosphatases remains to be determined [9].

The integrin cytoplasmic domains play a central role in integrin activation [41-42]. However, the short integrin cytoplasmic tails lack enzymatic activity, and so depend on recruitment of adaptor molecules and signaling proteins for effector functions [36]. Talin is a major cytoskeletal protein that co-localizes with and binds to integrins and to actin and actin-binding proteins such as vinculin [43]. It has been demonstrated that binding of talin to the $\beta$ cytoplasmic domain is a crucial, final step in activation of several classes of integrins [44-45]. Knockdown of talin expression in 
$\mathrm{CHO}$ (Chinese-hamster ovary) cells inhibits the activation of both $\beta 1$ and $\beta 3$ integrins without altering integrin expression [44]. NMR studies suggest that direct disruption of $a-\beta$ tail interaction by the talin head domain result in integrin activation [46]. Proposed a two-step activation model, the talin head domain first recognizes the high-affinity binding site in the membrane-distal region, which provides a strong linkage between the talin and the integrin $\beta$ tail, and subsequently binds to a second lower-affinity membrane proximal site that is involved in $\alpha-\beta$ association, triggering separation of the tails and integrin activation [47-48]. Although talin is an important player in integrin activation mechanisms, the possibility remains that other integrin tail-binding proteins can substitute for talin. For example, many other PTB-domain-containing proteins including Numb, Dok-1, ICAP-la (integrin cytoplasmic domainassociated protein-la) and Kindlins bind to integrin $\beta$ tails in a similar fashion to talin [49].

Integrin activation requires transmission of conformational rearrangements from the cytoplasmic face to the extracellular domain. The interaction between the membrane-proximal regions of the $\alpha$ and $\beta$ subunits is believed to be stabilized by a salt bridge between a conserved arginine residue in the a tail and an aspartate residue in the $\beta$ tail and by the hydrophobic residues immediately N-terminal to the arginine and aspartate residues [50]. Mutations that disrupt this 'clasp' lead to integrin activation, and integrins can be constitutively activated by deletion or mutations in these membrane-proximal sequences [42]. These data together strongly indicate that this membrane-proximal interaction plays an essential role as a stabilizer in the association of the a and $\beta$ membrane proximal regions, maintaining the integrins in a low-affinity state. In addition, mutational analysis and computational modeling together suggest that a helical interface between the integrin $\alpha$ and $\beta$ subunit transmembrane domains stabilizes the inactive state, and suggest that disruption of this helical transmembrane interface leads to activation [51] [52].

\section{LIGANGDS OF INTEGRINS}

The majority of integrin ligands are protein components of ECM (Table 1). ECM is assembled from components synthesized and deposited outside the cell surface that provide structural and functional integrity to connective tissues and organs [53]. The ECM can also serve as a reservoir or provisional ma- trix for growth factors and plasma proteins found in the blood [54]. The protein components of ECM can be divided into three major classes: (1) structural proteins such as the collagens and elastin (although collagen can also have functional properties); (2) multidomain adhesive glycoproteins such as fibronectin, vitronectin, and laminin; and (3) matricellular proteins such as secreted protein acidic and rich in cysteine (SPARC; also known as osteonectin and BM-40), thrombospondin 1 (TSP1) and 2 (TSP2), tenascin C and $X$, and osteopontin [53]. Among them, collagen primarily provides tensile strength to the tissue and elastin is responsible for the elastic recoil. Fibronectin, an adhesive glycoprotein, is a multifunctional protein that can act as a structural molecule owing to its fibrillar architecture, a biological glue that mediates interactions between cells and other ECM proteins, or a bridge forming cell to cell contacts [55]. Matricellular proteins are secreted macromolecules that interact with cell-surface receptors, ECM, growth factors, and proteases but do not function as structural molecules per se [56]. These glycoproteins regulate interactions between cells and ECM. For instance, SPARC, TSP1, and tenascin $\mathrm{C}$ disrupt cell-matrix interactions (i.e., are counteradhesive) - a critical component of angiogenesis and tissue remodeling [57].

All five $\alpha V$ integrins, two $\beta 1$ integrins (a5, a8) and $a I I b \beta 3$ share the ability to recognize ligands containing an RGD tripeptide active site, which is shared by The RGD binding integrins are among the most promiscuous in the family, with $\beta 3$ integrins in particular binding to a large number of ECM and soluble vascular ligands including fibronectin, fibrinogen, vitronectin, vWF, LAP-TGF $\beta$ and Del-1. Although many ligands are shared by this subset of integrins, the rank order of ligand affinity varies, presumably reflecting the preciseness of the fit of the ligand RGD conformation with the specific a- $\beta$ active site pockets [58].

Collagens are a major family of structural ECM proteins and characterized by the presence of triple helical regions. Cells employ four different aI domain containing integrins including $\alpha 1, a 2, a 10$, and $\alpha 11$ to maintain holds with them. Immunoglobulin superfamily members also act as ligands for several integrins, and the best characterized integrin ligands are VCAM-1 (Vascular Cell Adhesion Molecule) and the ICAMs. VCAM- 1 binds to $\alpha 4 \beta 1, \alpha V \beta 3$ and $\alpha 4 \beta 7$, whereas the leukocyte-specific CD11/CD18 integrins (including LFA-1 and Mac-1) bind to ICAMs [59]. 
Table I. Ligands and distribution of integrins

\begin{tabular}{|c|c|c|c|}
\hline Integrins & Ligands & Cellular and tissue distribution & Potential implications \\
\hline$\alpha v \beta 1$ & Ln, Fn, Opn, Vn & SMCs, fibroblasts, osteoclasts, tumor cells & Vascular disorders \\
\hline$\alpha v \beta 3$ & $\begin{array}{l}\text { Fg, Vn, Tn, Opn, } \\
\text { Tsp, Fn, PECM, } \\
\text { MMP2, VEFG-A, } \\
\text { Fibrillin-1, vWF }\end{array}$ & $\begin{array}{l}\text { Endothelial cells, SMCs, osteoclasts, } \\
\text { platelets, fibroblasts, tumor cells, epithelial } \\
\text { cells, leukocytes, chondrocytes }\end{array}$ & $\begin{array}{l}\text { Angiogenesis, restenosis, } \\
\text { vascular disorders, osteoporosis }\end{array}$ \\
\hline$\alpha v \beta 5$ & $\begin{array}{l}\text { Opn, Fg, Vn, Fn, } \\
\text { Tsp }\end{array}$ & $\begin{array}{l}\text { Endothelial cells, SMCs, osteoclasts, } \\
\text { platelets, epithelial cells, leukocytes, } \\
\text { chondrocytes }\end{array}$ & Angiogenesis, vascular disorders \\
\hline$\alpha v \beta 6$ & $\begin{array}{l}\text { Fn, Fg, Vn, Tn, } \\
\text { LAP-TGF } \beta, \\
\text { Fibrillin-1 }\end{array}$ & Epithelial cells, carcinoma cells & $\begin{array}{l}\text { Promotion of cell migration, } \\
\text { control of cell proliferation, } \\
\text { activation of TGFbs, suppression } \\
\text { of apoptosis, modulation of } \\
\text { protease activity and mediating } \\
\text { invasion of carcinoma cells. }\end{array}$ \\
\hline$\alpha v \beta 8$ & Vn & $\begin{array}{l}\text { Melanoma, kidney, brain, ovary, uterus, } \\
\text { placenta }\end{array}$ & $\begin{array}{l}\text { Proper brain blood vessel } \\
\text { development }\end{array}$ \\
\hline$\alpha 1 \beta 1$ & $\begin{array}{l}\text { Cn VI, Cn I, Ln, } \\
\text { Semaphorin 7A }\end{array}$ & Chondrocytes, endothelial cells & $\begin{array}{l}\text { Induction of laminin-1 } \\
\text { expression }\end{array}$ \\
\hline$\alpha 2 \beta 1$ & $\begin{array}{l}\text { Cn I, Cn IV, Ln, } \\
\text { Echovirus } 1 \text {, } \\
\text { Tenascin }\end{array}$ & $\begin{array}{l}\text { Keratinocytes, chondrocytes, platelets } \\
\text { endothelial cells }\end{array}$ & Wound healing \\
\hline$\alpha 3 \beta 1$ & Ln, VEFG-A, Tsp & Keratinocytes & $\begin{array}{l}\text { Branching morphogenesis in } \\
\text { mammary epithelia, } \\
\text { tumorigenesis and metastasis }\end{array}$ \\
\hline$\alpha 4 \beta 1$ & $\begin{array}{l}\text { Fn, VCAM-1, } \\
\text { MadCAM-1 }\end{array}$ & Leukocytes, endothelial cells & $\begin{array}{l}\text { Adhesion and extravasation of } \\
\text { lymphocytes, monocytes and } \\
\text { progenitor cells tumor homing }\end{array}$ \\
\hline$\alpha 5 \beta 1$ & Fn, Fibrillin-1, Tsp & Chondrocytes, endothelial cells & Angiogenesis \\
\hline$\alpha 6 \beta 1$ & Ln, Tsp, CYR61 & Chondrocytes, endothelial cells & Angiogenesis \\
\hline$\alpha 7 \beta 1$ & Ln, & Differentiated muscle cells & Unclear \\
\hline$\alpha 8 \beta 1$ & Fn, LAP-TGF $\beta$ & Smooth muscle cells & Fibrotic response \\
\hline$\alpha 9 \beta 1$ & $\begin{array}{l}\text { Tn, VCAM-1, } \\
\text { VEFG-A, VEGF-C, } \\
\text { VEGF-D, and HGF }\end{array}$ & Keratinocytes, endothelial cells & Lymphangiogenesis \\
\hline$\alpha 10 \beta 1$ & $\mathrm{Cn}$, & Chondrocytes, & Unclear \\
\hline$\alpha 11 \beta 1$ & $\mathrm{Cn}$ & Mesenchymal non-muscle cells & Embryonic development \\
\hline$\alpha 6 \beta 4$ & $\mathrm{Ln}$ & Endothelial cells & $\begin{array}{l}\text { Keratinocyte migration, } \\
\text { carcinoma invasion, keratinocyte } \\
\text { survival }\end{array}$ \\
\hline$\alpha \operatorname{IIb} \beta 3$ & $\mathrm{Fg}, \mathrm{Fn}, \mathrm{vWF}$ & Platelets & $\begin{array}{l}\text { Stable clot formation and } \\
\text { hemostasis }\end{array}$ \\
\hline$\alpha \mathrm{E} \beta 7$ & E-cadherin & Leukocytes & \\
\hline$\alpha \times \beta 2$ & $\begin{array}{l}\text { ICAM-1, Fg, iC3b, } \\
\text { factor X, heparin }\end{array}$ & Leukocytes & $\begin{array}{l}\text { Leukocyte adhesion deficiencies } \\
\text { (LAD), }\end{array}$ \\
\hline$\alpha \mathrm{L} \beta 2$ & ICAMs 1-5 & Leukocytes & $\begin{array}{l}\text { Multiple sclerosis and psoriasis, } \\
\text { LAD }\end{array}$ \\
\hline$\alpha \mathrm{M} \beta 2$ & $\begin{array}{l}\text { ICAM-2, Fg, Fn, } \\
\text { iC3b, factor X, } \\
\text { heparin }\end{array}$ & Leukocytes & LAD \\
\hline$\alpha \mathrm{D} \beta 2$ & $\begin{array}{l}\text { VCAM-1, Vn, } \\
\text { Plasmonogen }\end{array}$ & Leukocytes & LAD \\
\hline$\alpha 4 \beta 7$ & MAdCAM-1 & Leukocytes & Multiple sclerosis and psoriasis \\
\hline
\end{tabular}

*Fg, fibrinogen; Fn, fibronectin; Ln, laminin; Opn, osteopontin; Tn, tenascin; Tsp, thrombospondin; Vn, vitronectin; Cn, Collagen; vWF, von Willebrand factor 


\section{BIOLOGICAL AND PATHOLOGICAL FUNCTION OF INTEGRINS}

Cell adhesion is involved in many essential normal cellular and pathological functions including cell survival, growth, differentiation, migration, inflammatory responses, platelet aggregation, tissue repair and tumor invasion. Integrins are one of key family proteins for cell adhesion regulation through binding to a large number of extracellular matrix molecules and cell membrane proteins. Using knockout mice it has become evident that the integrins possess both redundant and nonredundant functions, and that lack of expression may result in a wide variety of effects ranging from blockage in pre-implantation to embryonic orperinatal lethality and developmental defects.

$\beta 1$ Integrin. The largest subgroup of integrins is formed by the $\beta 1$ subunit containing integrins which consist of 12 members with different ligand binding properties. Besides ECM proteins, some $\beta 1$ integrin containing receptors also interact with cellular receptors. For example, a4 $\beta 1$ and $\alpha 9 \beta 1$ bind to VCAM-1 and $a 4 \beta 1$ to MadCAM-1 [60]. During early embryogenesis totipotent embryonic cells differentiate and polarize to form endoderm, basement membrane (BM), and ectoderm. However, embryoid bodies derived from $\beta 1$-deficient ES cells develop endoderm, but do not form a BM, polarized ectoderm and a cavity [61]. $\beta 1$-integrin null embryos die by embyronic day (E)9.5-10.5 in utero owing to implantation defects [62-63]. The major function of $\beta 1$ integrin during early development may be to induce laminin-1 expression since exogenous addition of laminin 1 allows BM formation also in the absence of $\beta 1$ integrins, though the signaling pathway mediating the regulation is still unclear [64]. $\beta 1$ integrins are crucial for the attachment of basal keratinocytes to the BM, since loss of $\beta 1$ leads to widespread blisters between the epidermis and the BM. In addition, loss of $\beta 1$ integrin in skin decreases the proliferation of basal keratinocytes by about $70 \%$ [65]. Similarly to skin, $\beta 1$ integrins are important for the attachment to and maintenance of the $\mathrm{BM}$ in brain [66]. Although $\beta 1$ integrins are important ECM receptors, they are not generally required for cell migration. While some cells, such as keratinoctes or primordial germ cells, are highly dependent on $\beta 1$ integrin, other such as myoblasts, neurons and lymphocytes migrate normally also in the absence of $\beta 1$ integrin. Tumor cells expressing $\beta 1$ integrin formed significantly larger primary tumors and had a dramatically increased metastasis into liver and lung [67]. Moreover, ablation of the $\beta 1$ integrin gene in mammary epithelium dramatically impairs mammary tumorigenesis in mice [68]. However, in human patients, no clear correlation between tumor formation, invasion and $\beta 1$ integrin expression could be identified yet.

Integrins $\alpha 1 \beta 1$ and $\alpha 2 \beta 1$ are expressed on lymphatic endothelium in healing wounds in response to VEGF. Inhibition of these integrins blocked lymphangiogenesis in these wounds [69]. In normal animals, VEGFA treatment upregulates expression of both $\alpha 1 \beta 1$ and $\alpha 2 \beta 1$ on vascular endothelial cells. Function-blocking antibodies directed against both integrins reduced VEGFA-induced angiogenesis in vivo and reduced tumor growth and angiogenesis [70]. Tumors grown in $\alpha 1 \beta 1$-deficient mice grew more slowly and exhibited less angiogenesis, indicating an important role for this integrin in angiogenesis [71]. However, mice lacking $\alpha 2 \beta 1$ integrins exhibit increased B16F10 melanoma growth and angiogenesis when compared with wild-type mice [72]. By contrast, Lewis lung carcinoma (LLC) tumors did not exhibit increased angiogenesis or growth in $\alpha 2$-null mice. The different response resulted from different level of a VEGFR1 binding placental growth factor (PLGF) expression which was high from B16F10 melanoma cells and low from LLC cells. Enhanced angiogenesis was attributed to an increase in VEGFR1 expression and function on $\alpha 2$-null endothelial cells [72].

Integrin $\alpha 4 \beta 1$, a receptor for VCAM and fibronectin containing the CS1 region, is best known as a lymphocyte integrin involved in adhesion and extravasation of lymphocytes by binding to VCAM1 which is expressed on inflamed endothelial cells. Loss of integrin a4 during development leads to defects in placentation, heart development and coronary artery development, causing lethality between E10.0 and E12.0 [73]. It has been reported that integrin a $4 \beta 1$ was expressed on neo-vasculatures in both murine and human tumors and responded to VEGF, bFGF, IL1 and TNF. Antagonists of a $4 \beta 1$ blocked tumor neovascularization by induction of cell death of both endothelial cells and pericytes and decreased tumor growth in chick and murine models of tumor growth [74]. It has been proposed that integrin a $4 \beta 1$-VCAM1 interactions facilitated close proximity of the endothelial cells and pericytes, which promoted the survival of both endothelial cells and pericytes during angiogenesis [74]. Moreover, integrin $\alpha 4 \beta 1$ selectively promotes the homing of both endothelial progenitor cells and monocytes to neovascular tissue [75]. Treatment of mice bearing LLC tumors with antagonists of integrin $\alpha 4 \beta 1$ significantly suppressed the number of monocytes and progenitor cells found within tumors and reduced blood vessel density [76], indicating that the suppression of monocyte and 
progenitor cell homing to tumors by integrin $\alpha 4 \beta 1$ antagonists could be a useful supplementary approach to suppress tumor angiogenesis and growth.

Embryonic deletion of the integrin a5 subunit induces early mesenchymal abnormalities, leading to lethality of a5-null embryos [77]. Further studies using a5-null ES cells to grow teratocarcinomas showed decreased proliferation, increased apoptosis and decreased vascularization in teratocarcinomas derived from a5-null ES cells compared with controls [78]. Integrin a5 $\beta 1$ expression is induced in response to a variety of angiogenic stimuli, such as bFGF, IL8 and the ECM protein DEL1 (also known as EDIL3), but not by VEGF [79]. Integrin a5 $\beta 1$-mediated adhesion promotes endothelial cell migration and survival in vivo and in vitro by suppressing the activity of protein kinase A (PKA) [80]. Integrin a $5 \beta 1$ is poorly expressed on quiescent endothelium but its expression is significantly upregulated on endothelium during tumor angiogenesis in both mice and humans [81]. In some types of cancer, integrin a $5 \beta 1$ is also expressed on tumor cells and plays a direct role in tumor cell migration, invasion, and survival [82-84]. A small peptide antagonist (amino-acid sequence PHSCN) to integrin a5 $\beta 1$ significantly reduced neovascularization and formation of metastases in an animal model of prostate carcinoma that expresses integrin a5 31 [83, 85-86]. Expression of a $5 \beta 1$ is also upregulated during corneal angiogenesis [87].

Integrin a6 61 is expressed at high levels in capillary endothelial cells in vivo [88]. Unlike a6 $\beta 4$, which shows a preference for laminin 5, integrin a6 $\beta 1$ binds most laminin isoforms as well as other ECM proteins including CYR61, thrombospondin 1 and thrombospondin 2 [89]. As a6 integrin antagonists and a6 small interfering RNA constructs inhibit angiogenesis, it is possible that integrin a $6 \beta 1$ promotes angiogenesis. However, as these agents can block the function of both integrins a6 $\beta 1$ and a6 64 , it is not yet clear what part integrin a6 61 plays in tumor angiogenesis [88]. Antibody inhibitors of $\alpha 6$ integrin prevented endothelial cell tube formation in vitro, suggesting a role for $\alpha 6$ in the angiogenic process [88].

Integrin $\alpha 9 \beta 1$ is structurally similar to integrin a $4 \beta 1$. However, unlike $\alpha 4 \beta 1$, it is a receptor for a number of ECM proteins and cell surface receptors including tenascin $\mathrm{C}$, thrombospondin, osteopontin, IIICS fibronectin, VCAM1 and other ligands [90]. Integrin $\alpha 9 \beta 1$ is expressed on epithelia, osteoclasts, smooth muscle cells and also endothelial cells. a9 $\beta 1$ promotes VEGFA-stimulated angiogenesis by directly binding to VEGFA and blocking antibodies to a9 $\beta 1$ suppress VEGFA-induced angiogenesis [91]. However, other studies found that $\alpha 9 \beta 1$ also binds directly to the $\mathrm{N}$ terminus of thrombospondin and blocking antibodies to a9 $\beta 1$ inhibited angiogenesis induced by this thrombospondin fragment [92]. Integrin a9 $\beta 1$ also has a role in growth factor-mediated lymphangiogenesis as PROX1, a lymphatic endothelial cell-selective transcription factor, coordinately upregulates integrin a9 31 and VEGFR3 expression and endothelial cell motility in vivo [93]. This integrin promotes VEGFC- and VEGFD-stimulated cell migration by directly binding these growth factors and antagonism of a9 $\beta 1$ suppresses VEGFC-induced motility [94]. Taken together, these studies indicate that a9 $\beta 1$ has unique and crucial roles in lymphangiogenesis. Indeed, integrin a9 $\beta 1$-null mice die 8-12 days after birth owing to lethal defects in development of the lymphatic system; however, they do not exhibit obvious defects in development of blood vessels [95].

av $\beta 3$ Integrin. The integrin $\alpha v \beta 3$ is the first of the av integrins to be characterized and shown to regulate angiogenesis [96-97]. It binds with multiple components of the ECM including vitronectin, fibronectin, fibrinogen and osteopontin since they are all RGD-containing proteins. It has been found in 1994 that integrin $\operatorname{av} \beta 3$ was widely expressed on blood vessels in human tumor biopsy samples but not on vessels in normal human tissues. Its expression on endothelial cells is stimulated by angiogenic growth factors such as bFGF, TNFa and IL8 and it is upregulated on endothelium in tumors, wounds and sites of inflammation av $\beta 3$ integrin has a key role in endothelial cell survival and migration during angiogenesis [96] [98]. Antagonists of av $\beta 3$ inhibited angiogenesis and tumor growth in a variety of animal models of cancer and blocked corneal as well as choroidal angiogenesis in animal models of ocular disease [98-99]. In addition, integrin av $\beta 3$ antagonists induce endothelial cell apoptosis through a caspase 8-dependent cell death program [100]. In vitro studies revealed that agonists of endothelial cell av $\beta 3$, but not other integrins, suppressed p53 activity, blocked p21WAF1/CIP1 expression, and increased the bcl-2/bax ratio, thereby promoting cell survival [101]. Ligation of endothelial av $\beta 3$ integrin has also been shown to activate mitogen-activated protein kinase (MAPK), FAK and Src, among other kinases, resulting in cell proliferation, differentiation and migration [102].

Based on the sizable body of evidence addressed above, it is reasonable to draw the conclusion that integrin av $\beta 3$ promotes angiogenesis and endothelial cell survival and that antagonism of this integrin suppresses angiogenesis by inducing endothelial cell apoptosis in vitro and in vivo. Indeed, antagonists of $\beta 3$ integrin are being used in clinical trials as an- 
ti-angiogenic therapy, including the humanized monoclonal antibody Vitaxin and the RGD mimetic Cilengitide [103-104]. However, these agents did not appear to be as successful at inhibiting angiogenesis in clinical trials for cancer treatment as originally hoped [105]. Recently, it has been reported that low concentrations of RGD-mimetic integrin inhibitors promote VEGF mediated angiogenesis by altering av $\beta 3$ integrin and vascular endothelial growth factor receptor-2 trafficking, thereby stimulating tumor growth and angiogenesis [106].

More importantly, a series of genetically Knock-out studies forced researchers to reconsider the role of integrin av $\beta 3$ and av $\beta 5$ in angiogenesis. For example, genetic ablation of the av integrin subunit did not appear to affect developmental angiogenesis [107]. Even conditional deletion of av integrin in Tie2-expressing endothelial cells is not sufficient to affect angiogenesis either [108]. Furthermore, $\beta 3$ null and $\beta 3 / \beta 5$ doubly deficient mice produce vascular networks without obvious defects during developmental angiogenesis, and more surprisingly, display enhanced tumor growth and pathological angiogenesis [109-110]. However, male mice lacking $\beta 3$ integrin exhibit coronary capillaries of irregular endothelial thickness, with endothelial protrusions into the lumen, and expanded cytoplasmic vacuoles. These defective coronary vessels can be normalized by administration of inhibitors of VEGF or VEGF receptor 2 (VEGFR2, also known as KDR), suggesting that enhanced VEGF signaling might compensate for the loss of $\beta 3$ integrin [111]. In addition, with a mouse knockin model, it has been demonstrated that the phosphorylation of Tyr747 and Tyr459 in $\beta 3$ integrin participates in enhancing pathological angiogenesis [112].

All considered, the above studies suggest that av $\beta 3$ integrin may have both positive and negative roles during angiogenesis. Indeed, av $\beta 3$ can bind a plethora of factors that are thought to enhance angiogenesis including VEGFR2, vitronectin, fibronectin, Del1, ANGPTL3, CYR61, bone sialoprotein, thrombin, and can also bind to several factors that are thought to induce anti-angiogenic effects including thrombosondin, angiostatin, and tumstatin [113]. Another explanation is that functioning as a biosensor, av $\beta 3$ may promote angiogenesis in the ligated state, but when ligands are absent or ligand binding is antagonized, av $\beta 3$ may activate a death pathway to inhibit angiogenesis. Thus, depending on the microenvironment and the ligation state, integrins promote or inhibit angiogenesis by positively or negatively regulating cell survival [114]. In this way, integrin av $\beta 3$ appears to function as a regulator of angiogenesis by balancing opposing signals in the tumor microenvironment. av $\beta 5$ integrin. All though integrin av $\beta 5$ binds with similar ECM components with av $\beta 3$, the related angiogenic promoting pathway is distinct from that regulated by av $\beta 3$. For example, anti-av $\beta 3$ antibodies blocked angiogenesis induced by bFGF, whereas antibodies that target av $\beta 5$ blocked the angiogenesis induced by VEGF in both the rabbit corneal eye pocket and the chick chorioallantoic membrane assay [115]. The VEGF-av $\beta 5$ pathway is dependent on Src kinase and protein kinase C30. In vivo angiogenesis assays showed av $\beta 5$ is required for TGF- $\beta$ and VEGF-mediated angiogenesis and VEGF acted through av $\beta 5$ to promote vascular permeability [116], indicating av $\beta 5$ may also promote tumor metastasis [117]. However, integrin av $\beta 5$-null mice exhibit completely normal development and normal angiogenesis [118], indicating that this integrin is not required for vascular development.

Genetic ablations of the av subunit, which eliminate expression of integrins $\operatorname{av} \beta 1, \operatorname{av} \beta 3, \operatorname{av} \beta 5, \operatorname{av} \beta 6$ and $\operatorname{av} \beta 8$ suggest that, in some mice, av integrins are not required for blood vessel development in most tissues. Twenty percent of embryos lacking av integrins survive to birth with normal blood vessels in many tissues. However, $80 \%$ of mice die in utero between E10.5 and E11.5 with defective placental blood vessels. The remaining $20 \%$ of av-null mice die shortly after birth with severe brain and intestinal haemorrhage, with distended and leaky vessels in these tissues [107]. Thus, av integrins appear to have key roles in embryonic development of blood vessels in tissues such as placenta and brain.

av $\beta 6$ integrin. The av $\beta 6$ receptor is the only known integrin that is restricted exclusively to epithelial cells [119]. The av $\beta 6$ integrin is expressed primarily during embryonic development and is not expressed constitutively in healthy epithelia. However, av $\beta 6$ is upregulated during tissue remodeling, including wound healing and carcinogenesis [120]. av $\beta 6$ facilitates keratinocyte adhesion and migration on fibronectin, tenascin and vitronectin, all of which are components of the early wound matrix [121]. Using mouse $\beta 6^{\%}$ - keratinocytes, Huang et al. found that av $\beta 6$ expression promotes keratinocyte migration through a pathway involvling protein kinase $C$ [122]. Binding of av $\beta 6$ to its ligand upregulated secretion of the pro-enzyme form of type IV collagenase, MMP-9, and exogenous activation of MMP-9 further increased keratinocyte migration [123]. Thomas et al. demonstrated that binding of av $\beta 6$ to the TGFb1 latency associated peptide (LAP) promotes cell migration and MMP-9 expression, and also that cells will invade towards soluble LAP in an av $\beta 6$-dependent manner [124]. In addition, TGFb1 induces de novo expression 
of av $\beta 6$ in normal human keratinocytes [125] and on the non-transformed keratinocyte cell line, HaCaT [126].

To date, av $\beta 6$ expression has been reported in carcinomas of the lung, breast, pancreas, stomach, colon, ovary, salivary gland as well as oral and skin squamous cell carcinoma [120, 127-131]. Elevated av $\beta 6$ expression facilitated the invasion and dissemination of colon carcinoma cells in vivo [132-133]. The $\beta 6$ overexpressing cell line was significantly more invasive, which was, in part, through av $\beta 6$-dependent upregulation of the type IV collagenase MMP-9 [134-135]. High av $\beta 6$ expression correlated with elevated UPA, UPAR and MMP-9 in ovarian carcinoma cell lines [136]. It has also been proposed that contribution of av $\beta 6$ for promoting cancer progression in vivo is related to the mechanism of epithelial-mesenchymal transition (EMT) by activating latent TGF-b [137]. The upregulation of av $\beta 6$ related with the poor prognosis [132], suggesting that av $\beta 6$ expression may be useful in predicting malignant transformation. Indeed, the integrin av $\beta 6$ now emerges as an attractive new candidate as a therapeutic target for metastatic colon carcinoma. However, epithelial cells in samples of lichen planus (a chronic mucocutaneous disease) have also been shown to express av $\beta 6$ suggesting that av $\beta 6$ expression per se is insufficient to drive malignant progression [138]. The net effect on tumor behavior is likely to depend on the stage of tumor development. In the later stages of tumor development, as cells become refractory to growth inhibition, then the role of LAP in promoting both av $\beta 6$-dependent cell movement and MMP-9 expression may become prominent, culminating in a pro-oncogenic effect of TGFb [139].

a6 $\beta 4$ Integrin. a6 $\beta 4$ plays a key role in the formation and stabilization of junctional adhesion complexes called hemidesmosomes (HDs) that are connected to the intermediate filament (IF) system, as well as in the regulation of a variety of signaling processes. Increased expression of a6 64 and changes in its distribution were then correlated with increased aggressiveness of tumors and poor prognosis [140]. $\beta 4$ subunit has an unusual size of approximately $200 \mathrm{kDa}$, which is due to an unusually long cytoplasmic domain of over 1,000 amino acids [141]. This domain contains two pairs of type III fibronectin (FNIII) domains, separated by a connecting segment (CS) [142]. $\beta 4$ knockout mice developed severe blistering of the skin [143]. Moreover, a mutation in the $\beta 4$ gene is responsible for the pyloric atresia associated with junctional epidermolysis bullosa (EB) syndrome in humans. It has been found that interaction between a6 $\beta 4$ and plectin is critical for proper HD assembly and at least two sites on plectin and three on $\beta 4$ mediate their interaction. The actin binding domain (ABD) of plectin binds to the first pair of FNIII domains and part of the CS of $\beta 4$ [144]. Two other HD components, BP180 and BP230, bind to the third FNIII domain of $\beta 4$ and to a region comprising the C-terminal end of the CS and the second pair of FNIII domains, respectively [145]. The a6 subunit of a6 $\beta 4$ interacts with the tetraspanin CD151 [146].

Apart from promoting keratinocytes migration, studies on the invasion of carcinoma cells revealed a role for a634-dependent activation of phosphatidylinositol (PI)-3 kinase, which is an upstream regulator of Rac1 [147]. Since growth factors activate enzymes that initiate the disassembly of HDs, the presence of overactive growth factor receptors may explain why a6 $\beta 4$ is unable to initiate HD formation in many carcinoma cells. In fact, a6 $\beta 4$ cooperates with several different tyrosine kinases in carcinoma cells to promote invasion, including c-met (hepatocyte growth factor receptor), ErbB2 and ErbB1 [148]. There is evidence that proteins other than tyrosine kinases can cooperate with a6 $\beta 4$ to promote invasion. For example, invasion of breast carcinoma cells is stimulated by promoting Rab11-mediated vesicular trafficking under hypoxic conditions [149].

Leukocytes specific integrins. The arrest of leukocytes rolling on target vascular beds involves rapid formation of shear-resistant adhesions by specialized leukocyte integrins. This arrest can be mediated by integrins that contain the $\beta 2$ subunit, e.g. aL $\beta 2$ (leukocyte functionassociated antigen-1 (LFA-1)) or a4 subunit, e.g. a $4 \beta 1$ (very late antigen-4 (VLA-4)). In leukocytes, integrins are involved in slow rolling, adhesion strengthening, and transendothelial migration [150-151]. Lymphocyte and myeloid cells cease rolling and arrest on lymph node high endothelial venules as well as on peripheral tissues upon activation of at least one of the four major leukocyte integrins: VLA-4, a4 $\beta 7$, LFA-1, and the myeloidspecific integrin (integrin aM $\beta 2$ (Mac-1)) [152]. In addition, these integrins transmit signals that facilitate respiratory burst, complement-mediated phagocytosis, cytokine production, proliferation, survival, differentiation, degranulation, and cellular polarization. Loss or reduced $\beta 2$ on cell surface, defects in $\beta 2$ signaling, mutations in $\beta 2$ will cause leukocyte adhesion deficiencies (LAD) [153].

Most circulating leukocytes maintain their integrins in largely low affinity state [154]. Leukocyte integrins must undergo in situ modulation to develop high avidity for their endothelial ligands to establish shear-resistant adhesion and firm leukocyte arrest on the target endothelial site [155]. For most leukocytes, 
this dramatic change in integrin affinity is triggered when the rolling leukocyte encounters and rapidly responds to a proper chemoattractant signal presented on the apical endothelial surface [156]. The distribution of LFA-1 integrins to the leading edge of a polarized leukocyte is reported to proceed through a signaling cascade involving Rap1 and its downstream effectors RAPL and the threonine-serine kinase, Mst1 [157]. Integrins play key roles in cellular migration acting both as adhesive molecules that maintain locomotion over the apical endothelial surface and as signaling molecules, which, together with chemokine signals, maintain polarity and motility [158].

Leukocyte integrins are recognized therapeutic targets in various diseases, and integrin blocking monoclonal antibodies (natalizumab against a4 integrins and efalizumab against LFA-1) are already used in the clinic against multiple sclerosis and psoriasis [159-160]. Leukocyte adhesion cannot be inhibited by compounds containing the RGD sequence, but longer peptides to recognition sites in ICAM molecules or microbe-derived ICAM-1 inhibitors do show inhibitory activity [161-162]. It has been reported that promatrix metalloproteinases (proMMPs), particularly proMMP-9, are potent ligands of the leukocyte $\beta 2$ integrins and translocating proMMP-9/ $\alpha M \beta 2$ complex is part of the cell surface machinery guiding neutrophil migration [163], suggesting that a promising therapeutic approach could be to disrupt the association between the matrix metalloproteases and integrins. It has also been found that the Del-1 protein is an important endogenous inhibitor of leukocyte adhesion [164]. The Del-1 protein is a secreted protein expressed by endothelial cells in immunoprivileged tissues, such as the brain, the eye, and the lung. Although a secreted molecule, Del-1 is absent from plasma and is rather localised to endothelial cells and/or the extracellular matrix [164]. In fact, it binds to the $\beta 2$ integrins (LFA-1, Mac-1) and when coated on plastic, leukocytes adhere to the protein. However, leukocyte binding to ICAM-1 is inhibited when both Del-1 and ICAM-1 are present. Del-1 knockout mice show a strong activation of adhesion and of inflammatory cell recruitment [164].

\section{PERSPECTIVES OF INTEGRINS AS IMAGING AND THERAPY TARGETS}

Integrins are ideal pharmacological targets based on both the key role they played in angiogenesis, leukocytes function and tumor development and easy accessibility as cell surface receptors interacting with extracellular ligands [1]. So far, the integrin superfamily represents the best opportunity of targeting both antibodies and small-molecule antagonists for both therapeutic and diagnostic utility in various key diseases [165]. Preclinical studies and clinical trials showed that quite a few integrin targeting antibodies were effective to block tumor growth and metastasis. Most of studies focused on av integrins including MEDI-522 (vitaxin) against av $\beta 3$ [98], CNTO 95 against both av $\beta 3$ and av $\beta 5$ [166], 17E6 against av $\beta 3$, $\operatorname{av} \beta 5$ and $\operatorname{av} \beta 1$ [167]. Besides, antibodies targeting to other integrins have been developed. For example, Tysabri (natalizumab), an antibody which blocks a 4 integrins and inhibits the a4-mediated adhesion of leukocytes to their counter receptor was used for treatment of patients with relapsing forms of multiple sclerosis (MS) [168]. Small molecular antagonists, mainly based on RGD containing peptides and RGD peptidomimetic [169-171], also showed potent inhibition of angiogenesis. More detailed information can be found in several recently published review articles $[1,172]$.

Integrin ligands are also under investigation as tumor endothelium-targeted diagnostic agents and integrin targeting is proving useful in tumor imaging. Both peptide and antibody-based diagnostic agents targeting RGD-binding integrins or av integrins have been evaluated in animal models of cancer after ${ }^{18} \mathrm{~F}$ or ${ }^{64} \mathrm{Cu}$ labeling. Tumor xenografts with positive integrin av $\beta 3$ expression were visualized clearly on PET images [173-175]. Other imaging modalities besides PET have also been investigated for integrin av $\beta 3$ targeted imaging. For example, integrin av-targeted ultrasound microbubbles preferentially bound neovasculature at the periphery of experimental tumors [176]. The clinical significance of molecular imaging with integrin-targeting agents may be useful for lesion detection and grading. In addition, imaging will help identify appropriate patients for integrins related therapy and monitor the therapeutic responses. More important, integrin-targeting agents might also be useful in selectively delivering chemotherapeutics or gene therapeutic agents to tumors, thus minimizing systemic toxicities. For example, after fused with a RGD targeting moiety, RGD4C-TNF showed improved tumor accumulation and therapy effect in a human breast tumor model [177].

With regard to activity, signaling and regulation of integrins, evidences are accumulating with more crystal structures deciphered and new models established. However, the integrin pathways are still not fully understood due to extreme complexity. Besides their ligands, increasing number of biomolecules has been identified interacting with integrins including VEGF/VEGFR [178], HER2 [179], MMPs [180], uPAR [181]. Moreover, it has been found that ligand-bound integrins also actively suppress the activation of other 
integrins in the same cell utilizing different signaling pathways. For example, when a $2 \beta 1$ is ligated, both a5 $\beta 1$ and $\alpha \mathrm{V} \beta 3$ will be suppressed through PKA. When a5 51 is ligated, $\alpha 2 \beta 1$ will be suppressed through PKCa [182]. Integrins are also known to have transdominant roles over other integrins and can thus control overall cell behavior [183]. After epithelial integrity is restored in wounds, av $\beta 6$ expression will be strong upregulated. However, mutating the $\beta 6$ cytoplasmic domain by removing the terminal 11 amino acids prevents this density-dependent upregulation of $\operatorname{av} \beta 6$ and replaces it by upregulating av $\beta 5$. This provides evidence that the expression of these integrins is linked and expression may be switched from one to the other [135].

So far, a lot of breakthroughs in integrin research have been made with purified integrins, or I-domains and their ligands. However, it is becoming increasingly apparent that integrin mediated cell adhesion is unusually complex. Thus, it is critical to study the events occurring at the cellular and organism levels in a temporal manner to make more meaningful conclusions. It is very promising for molecular imaging of living cells or animal models to meet the requirement. For example, microscopic imaging with FRET could identify integrin-integrin interaction and integrin-other proteins interaction in living cells [184] [185]. PET imaging with positron emission radioisotopes labeled integrin-targeting probes could visualize expression and regulation of integrins in animal models in a real-time mode [186]. We believe integrating data from both microscopic and macroscopic methods will quicken our steps on the long scientific journey to decipher the integrins related pathways.

\section{ACKNOWLEDGEMENT}

This work was supported by the intramural Research Program (IRP) of the National Institute of Biomedical Imaging and Bioengineering (NIBIB), National Institutes of Health (NIH). Dr. G. Niu currently is an Imaging Sciences Training Fellowship jointly supported by the Radiology and Imaging Sciences Department, NIH Clinical Center and the Intramural Research Program, NIBIB, NIH.

\section{CONFLICT OF INTEREST}

The authors have declared that no conflict of interest exists.

\section{REFERENCES}

1. Lu X, Lu D, Scully M, Kakkar V. The role of integrins in cancer and the development of anti-integrin therapeutic agents for cancer therapy. Perspect Medicin Chem. 2008;2:57-73.

2. Hynes RO. Integrins: a family of cell surface receptors. Cell. 1987:48:549-54.

3. Hynes RO. Integrins: versatility, modulation, and signaling in cell adhesion. Cell. 1992;69:11-25.

4. Serini G, Valdembri D, Bussolino F. Integrins and angiogenesis: a sticky business. Exp Cell Res. 2006;312:651-8.

5. Brakebusch C, Bouvard D, Stanchi F, Sakai T, Fassler R. Integrins in invasive growth. J Clin Invest. 2002;109:999-1006.

6. Hynes RO. Integrins: bidirectional, allosteric signaling machines. Cell. 2002;110:673-87.

7. Vogel V, Sheetz M. Local force and geometry sensing regulate cell functions. Nat Rev Mol Cell Biol. 2006;7:265-75.

8. Ginsberg MH, Partridge A, Shattil SJ. Integrin regulation. Curr Opin Cell Biol. 2005;17:509-16.

9. Springer TA. Complement and the multifaceted functions of VWA and integrin I domains. Structure. 2006;14:1611-6.

10. Xiong JP, Stehle T, Diefenbach B, Zhang R, Dunker R, Scott DL, et al. Crystal structure of the extracellular segment of integrin aVß3. Science. 2001;294:339-45.

11. Gahmberg CG, Fagerholm SC, Nurmi SM, Chavakis T, Marchesan S, Gronholm M. Regulation of integrin activity and signalling. Biochim Biophys Acta. 2009;1790:431-44.

12. Takagi J. Structural basis for ligand recognition by integrins. Curr Opin Cell Biol. 2007;19:557-64.

13. Lee JO, Bankston LA, Arnaout MA, Liddington RC. Two conformations of the integrin A-domain (I-domain): a pathway for activation? Structure. 1995;3:1333-40.

14. Lee JO, Rieu P, Arnaout MA, Liddington R. Crystal structure of the A domain from the a subunit of integrin CR3 (CD11b/CD18). Cell. 1995;80:631-8.

15. Shimaoka M, Xiao T, Liu JH, Yang Y, Dong Y, Jun CD, et al. Structures of the aL I domain and its complex with ICAM-1 reveal a shape-shifting pathway for integrin regulation. Cell. 2003;112:99-111.

16. Emsley J, Knight CG, Farndale RW, Barnes MJ, Liddington RC. Structural basis of collagen recognition by integrin a2 $\beta 1$. Cell. 2000;101:47-56.

17. Song G, Yang Y, Liu JH, Casasnovas JM, Shimaoka M, Springer TA, et al. An atomic resolution view of ICAM recognition in a complex between the binding domains of ICAM-3 and integrin aLß2. Proc Natl Acad Sci U S A. 2005;102:3366-71.

18. Luo BH, Carman CV, Springer TA. Structural basis of integrin regulation and signaling. Annu Rev Immunol. 2007;25:619-47.

19. Nishida N, Xie C, Shimaoka M, Cheng Y, Walz T, Springer TA. Activation of leukocyte $\beta 2$ integrins by conversion from bent to extended conformations. Immunity. 2006;25:583-94.

20. Takagi J, Strokovich K, Springer TA, Walz T. Structure of integrin a5 $\beta 1$ in complex with fibronectin. EMBO J. 2003;22:4607-15.

21. Xiong JP, Stehle T, Zhang R, Joachimiak A, Frech M, Goodman $\mathrm{SL}$, et al. Crystal structure of the extracellular segment of integrin $\alpha v \beta 3$ in complex with an Arg-Gly-Asp ligand. Science. 2002;296:151-5.

22. Xiao T, Takagi J, Coller BS, Wang JH, Springer TA. Structural basis for allostery in integrins and binding to fibrinogen-mimetic therapeutics. Nature. 2004;432:59-67.

23. Curnis F, Longhi R, Crippa L, Cattaneo A, Dondossola E, Bachi A, et al. Spontaneous formation of L-isoaspartate and gain of function in fibronectin. J Biol Chem. 2006;281:36466-76.

24. Takahashi S, Leiss M, Moser M, Ohashi T, Kitao T, Heckmann $\mathrm{D}$, et al. The RGD motif in fibronectin is essential for 
development but dispensable for fibril assembly. J Cell Biol. 2007;178:167-78.

25. DiCara D, Rapisarda C, Sutcliffe JL, Violette SM, Weinreb PH, Hart IR, et al. Structure-function analysis of Arg-Gly-Asp helix motifs in av $\beta 6$ integrin ligands. J Biol Chem. 2007;282:9657-65.

26. Shiu JH, Chen CY, Chang LS, Chen YC, Lo YH, Liu YC, et al. Solution structure of gamma-bungarotoxin: the functional significance of amino acid residues flanking the RGD motif in integrin binding. Proteins. 2004;57:839-49.

27. Pasterkamp RJ, Peschon JJ, Spriggs MK, Kolodkin AL. Semaphorin 7A promotes axon outgrowth through integrins and MAPKs. Nature. 2003;424:398-405.

28. Suzuki K, Okuno T, Yamamoto M, Pasterkamp RJ, Takegahara $\mathrm{N}$, Takamatsu H, et al. Semaphorin 7A initiates T-cell-mediated inflammatory responses through a1 $\beta 1$ integrin. Nature. 2007;446:680-4.

29. Aumailley M, Bruckner-Tuderman L, Carter WG, Deutzmann R, Edgar D, Ekblom P, et al. A simplified laminin nomenclature. Matrix Biol. 2005;24:326-32.

30. Nishiuchi R, Takagi J, Hayashi M, Ido H, Yagi Y, Sanzen N, et al. Ligand-binding specificities of laminin-binding integrins: a comprehensive survey of laminin-integrin interactions using recombinant a3 $\beta 1$, a6 $\beta 1, \alpha 7 \beta 1$ and a6 $\beta 4$ integrins. Matrix Biol. 2006;25:189-97.

31. Ido H, Harada K, Futaki S, Hayashi Y, Nishiuchi R, Natsuka Y, et al. Molecular dissection of the a-dystroglycan- and integrin-binding sites within the globular domain of human laminin-10. J Biol Chem. 2004;279:10946-54.

32. Kunneken K, Pohlentz G, Schmidt-Hederich A, Odenthal U, Smyth N, Peter-Katalinic J, et al. Recombinant human laminin-5 domains. Effects of heterotrimerization, proteolytic processing, and N-glycosylation on a $3 \beta 1$ integrin binding. J Biol Chem. 2004;279:5184-93.

33. Arnaout MA, Mahalingam B, Xiong JP. Integrin structure, allostery, and bidirectional signaling. Annu Rev Cell Dev Biol. 2005;21:381-410.

34. Xiong JP, Stehle T, Goodman SL, Arnaout MA. New insights into the structural basis of integrin activation. Blood. 2003;102:1155-9.

35. Zhang H, Casasnovas JM, Jin M, Liu JH, Gahmberg CG, Springer TA, et al. An unusual allosteric mobility of the C-terminal helix of a high-affinity aL integrin I domain variant bound to ICAM-5. Mol Cell. 2008;31:432-7.

36. Geiger B, Bershadsky A, Pankov R, Yamada KM. Transmembrane crosstalk between the extracellular matrix--cytoskeleton crosstalk. Nat Rev Mol Cell Biol. 2001;2:793-805.

37. Calderwood DA. Integrin activation. J Cell Sci. 2004;117:657-66.

38. Hughes PE, O'Toole TE, Ylanne J, Shattil SJ, Ginsberg MH. The conserved membrane-proximal region of an integrin cytoplasmic domain specifies ligand binding affinity. J Biol Chem. 1995;270:12411-7.

39. Arias-Salgado EG, Lizano S, Sarkar S, Brugge JS, Ginsberg MH, Shattil SJ. Src kinase activation by direct interaction with the integrin $\beta$ cytoplasmic domain. Proc Natl Acad Sci U S A. 2003;100:13298-302.

40. Cluzel C, Saltel F, Lussi J, Paulhe F, Imhof BA, Wehrle-Haller B. The mechanisms and dynamics of av $\beta 3$ integrin clustering in living cells. J Cell Biol. 2005;171:383-92.

41. Kim M, Carman CV, Springer TA. Bidirectional transmembrane signaling by cytoplasmic domain separation in integrins. Science. 2003;301:1720-5.

42. O'Toole TE, Mandelman D, Forsyth J, Shattil SJ, Plow EF, Ginsberg MH. Modulation of the affinity of integrin aIIb $\beta 3$ (GPIIb-IIIa) by the cytoplasmic domain of allb. Science. 1991;254:845-7.
43. Calderwood DA, Zent R, Grant R, Rees DJ, Hynes RO, Ginsberg $\mathrm{MH}$. The Talin head domain binds to integrin $\beta$ subunit cytoplasmic tails and regulates integrin activation. J Biol Chem. 1999;274:28071-4.

44. Tadokoro S, Shattil SJ, Eto K, Tai V, Liddington RC, de Pereda JM, et al. Talin binding to integrin $\beta$ tails: a final common step in integrin activation. Science. 2003;302:103-6.

45. Calderwood DA, Yan B, de Pereda JM, Alvarez BG, Fujioka Y, Liddington $\mathrm{RC}$, et al. The phosphotyrosine binding-like domain of talin activates integrins. J Biol Chem. 2002;277:21749-58.

46. Vinogradova O, Velyvis A, Velyviene A, Hu B, Haas T, Plow E, et al. A structural mechanism of integrin aIIb $\beta 3$ "inside-out" activation as regulated by its cytoplasmic face. Cell. 2002;110:587-97.

47. Garcia-Alvarez B, de Pereda JM, Calderwood DA, Ulmer TS, Critchley D, Campbell ID, et al. Structural determinants of integrin recognition by talin. Mol Cell. 2003;11:49-58.

48. Wegener KL, Partridge AW, Han J, Pickford AR, Liddington $\mathrm{RC}$, Ginsberg $\mathrm{MH}$, et al. Structural basis of integrin activation by talin. Cell. 2007;128:171-82.

49. Calderwood DA, Fujioka Y, de Pereda JM, Garcia-Alvarez B, Nakamoto T, Margolis B, et al. Integrin $\beta$ cytoplasmic domain interactions with phosphotyrosine-binding domains: a structural prototype for diversity in integrin signaling. Proc Natl Acad Sci U S A. 2003;100:2272-7.

50. Ma YQ, Yang J, Pesho MM, Vinogradova O, Qin J, Plow EF. Regulation of integrin aIIb $\beta 3$ activation by distinct regions of its cytoplasmic tails. Biochemistry. 2006;45:6656-62.

51. Stefansson A, Armulik A, Nilsson I, von Heijne G, Johansson S. Determination of $\mathrm{N}$ - and C-terminal borders of the transmembrane domain of integrin subunits. J Biol Chem. 2004;279:21200-5.

52. Luo BH, Springer TA, Takagi J. A specific interface between integrin transmembrane helices and affinity for ligand. PLoS Biol. 2004;2:e153.

53. Schultz GS, Wysocki A. Interactions between extracellular matrix and growth factors in wound healing. Wound Repair Regen. 2009;17:153-62.

54. Macri L, Silverstein D, Clark RA. Growth factor binding to the pericellular matrix and its importance in tissue engineering. Adv Drug Deliv Rev. 2007;59:1366-81.

55. Clark RA. Fibronectin matrix deposition and fibronectin receptor expression in healing and normal skin. J Invest Dermatol. 1990;94:128S-34S.

56. Bornstein P. Diversity of function is inherent in matricellular proteins: an appraisal of thrombospondin 1. J Cell Biol. 1995;130:503-6.

57. Sage EH. Regulation of interactions between cells and extracellular matrix: a command performance on several stages. J Clin Invest. 2001;107:781-3.

58. Humphries JD, Byron A, Humphries MJ. Integrin ligands at a glance. J Cell Sci. 2006;119:3901-3.

59. Rothlein R, Dustin ML, Marlin SD, Springer TA. A human intercellular adhesion molecule (ICAM-1) distinct from LFA-1. J Immunol. 1986;137:1270-4.

60. Brakebusch C, Fassler R. $\beta 1$ integrin function in vivo: adhesion, migration and more. Cancer Metastasis Rev. 2005;24:403-11.

61. Aumailley M, Pesch M, Tunggal L, Gaill F, Fassler R. Altered synthesis of laminin 1 and absence of basement membrane component deposition in $\beta 1$ integrin-deficient embryoid bodies. J Cell Sci. 2000;113 (Pt 2):259-68.

62. Fassler R, Meyer M. Consequences of lack of $\beta 1$ integrin gene expression in mice. Genes Dev. 1995;9:1896-908.

63. Stephens LE, Sutherland AE, Klimanskaya IV, Andrieux A, Meneses J, Pedersen RA, et al. Deletion of $\beta 1$ integrins in mice results in inner cell mass failure and peri-implantation lethality. Genes Dev. 1995;9:1883-95. 
64. Li S, Harrison D, Carbonetto S, Fassler R, Smyth N, Edgar D, et al. Matrix assembly, regulation, and survival functions of laminin and its receptors in embryonic stem cell differentiation. J Cell Biol. 2002;157:1279-90.

65. Brakebusch C, Grose R, Quondamatteo F, Ramirez A, Jorcano JL, Pirro A, et al. Skin and hair follicle integrity is crucially dependent on $\beta 1$ integrin expression on keratinocytes. EMBO J. 2000;19:3990-4003.

66. Graus-Porta D, Blaess S, Senften M, Littlewood-Evans A, Damsky $C$, Huang $Z$, et al. $\beta 1$-class integrins regulate the development of laminae and folia in the cerebral and cerebellar cortex. Neuron. 2001;31:367-79.

67. Brakebusch C, Wennerberg K, Krell HW, Weidle UH, Sallmyr A, Johansson S, et al. B1 integrin promotes but is not essential for metastasis of ras-myc transformed fibroblasts. Oncogene. 1999;18:3852-61.

68. White DE, Kurpios NA, Zuo D, Hassell JA, Blaess S, Mueller U, et al. Targeted disruption of $\beta 1$-integrin in a transgenic mouse model of human breast cancer reveals an essential role in mammary tumor induction. Cancer Cell. 2004;6:159-70.

69. Hong YK, Lange-Asschenfeldt B, Velasco P, Hirakawa S, Kunstfeld R, Brown LF, et al. VEGF-A promotes tissue repair-associated lymphatic vessel formation via VEGFR-2 and the $\alpha 1 \beta 1$ and $\alpha 2 \beta 1$ integrins. FASEB J. 2004;18:1111-3.

70. Senger DR, Claffey KP, Benes JE, Perruzzi CA, Sergiou AP, Detmar M. Angiogenesis promoted by vascular endothelial growth factor: regulation through $\alpha 1 \beta 1$ and $\alpha 2 \beta 1$ integrins. Proc Natl Acad Sci U S A. 1997;94:13612-7.

71. Pozzi A, Moberg PE, Miles LA, Wagner S, Soloway P, Gardner HA. Elevated matrix metalloprotease and angiostatin levels in integrin a 1 knockout mice cause reduced tumor vascularization. Proc Natl Acad Sci U S A. 2000;97:2202-7.

72. Zhang Z, Ramirez NE, Yankeelov TE, Li Z, Ford LE, Qi Y, et al. a2 $\beta 1$ integrin expression in the tumor microenvironment enhances tumor angiogenesis in a tumor cell-specific manner. Blood. 2008;111:1980-8.

73. Yang JT, Rayburn H, Hynes RO. Cell adhesion events mediated by a4 integrins are essential in placental and cardiac development. Development. 1995;121:549-60.

74. Garmy-Susini B, Jin H, Zhu Y, Sung RJ, Hwang R, Varner J. Integrin a $4 \beta 1$-VCAM-1-mediated adhesion between endothelial and mural cells is required for blood vessel maturation. J Clin Invest. 2005;115:1542-51.

75. Jin H, Aiyer A, Su J, Borgstrom P, Stupack D, Friedlander M, et al. A homing mechanism for bone marrow-derived progenitor cell recruitment to the neovasculature. J Clin Invest. 2006;116:652-62.

76. Jin H, Su J, Garmy-Susini B, Kleeman J, Varner J. Integrin a $4 \beta 1$ promotes monocyte trafficking and angiogenesis in tumors. Cancer Res. 2006;66:2146-52.

77. Yang JT, Rayburn H, Hynes RO. Embryonic mesodermal defects in a5 integrin-deficient mice. Development. 1993;119:1093-105.

78. Taverna D, Hynes RO. Reduced blood vessel formation and tumor growth in a5-integrin-negative teratocarcinomas and embryoid bodies. Cancer Res. 2001;61:5255-61.

79. Boudreau NJ, Varner JA. The homeobox transcription factor Hox D3 promotes integrin a $5 \beta 1$ expression and function during angiogenesis. J Biol Chem. 2004;279:4862-8.

80. Kim S, Harris M, Varner JA. Regulation of integrin av $\beta 3$-mediated endothelial cell migration and angiogenesis by integrin $a 5 \beta 1$ and protein kinase A. J Biol Chem. 2000;275:33920-8.

81. Kim S, Bell K, Mousa SA, Varner JA. Regulation of angiogenesis in vivo by ligation of integrin a $5 \beta 1$ with the central cell-binding domain of fibronectin. Am J Pathol. 2000;156:1345-62.
82. Gong J, Wang D, Sun L, Zborowska E, Willson JK, Brattain MG. Role of a5 $\beta 1$ integrin in determining malignant properties of colon carcinoma cells. Cell Growth Differ. 1997;8:83-90.

83. Livant DL, Brabec RK, Pienta KJ, Allen DL, Kurachi K, Markwart S, et al. Anti-invasive, antitumorigenic, and antimetastatic activities of the PHSCN sequence in prostate carcinoma. Cancer Res. 2000;60:309-20.

84. O'Brien V, Frisch SM, Juliano RL. Expression of the integrin a5 subunit in HT29 colon carcinoma cells suppresses apoptosis triggered by serum deprivation. Exp Cell Res. 1996;224:208-13.

85. Umeda N, Kachi S, Akiyama H, Zahn G, Vossmeyer D, Stragies $\mathrm{R}$, et al. Suppression and regression of choroidal neovascularization by systemic administration of an a5 $\beta 1$ integrin antagonist. Mol Pharmacol. 2006;69:1820-8.

86. Dietrich T, Onderka J, Bock F, Kruse FE, Vossmeyer D, Stragies $\mathrm{R}$, et al. Inhibition of inflammatory lymphangiogenesis by integrin a5 blockade. Am J Pathol. 2007;171:361-72.

87. Muether PS, Dell S, Kociok N, Zahn G, Stragies R, Vossmeyer $D$, et al. The role of integrin a5 $\beta 1$ in the regulation of corneal neovascularization. Exp Eye Res. 2007;85:356-65.

88. Lee TH, Seng S, Li H, Kennel SJ, Avraham HK, Avraham S. Integrin regulation by vascular endothelial growth factor in human brain microvascular endothelial cells: role of a $6 \beta 1$ integrin in angiogenesis. J Biol Chem. 2006;281:40450-60.

89. Leu SJ, Liu Y, Chen N, Chen CC, Lam SC, Lau LF. Identification of a novel integrin a $6 \beta 1$ binding site in the angiogenic inducer CCN1 (CYR61). J Biol Chem. 2003;278:33801-8.

90. Liao YF, Gotwals PJ, Koteliansky VE, Sheppard D, Van De Water L. The EIIIA segment of fibronectin is a ligand for integrins $\alpha 9 \beta 1$ and a4 $\beta 1$ providing a novel mechanism for regulating cell adhesion by alternative splicing. J Biol Chem. 2002;277:14467-74.

91. Vlahakis NE, Young BA, Atakilit A, Hawkridge AE, Issaka RB, Boudreau $N$, et al. Integrin a9 $\beta 1$ directly binds to vascular endothelial growth factor (VEGF)-A and contributes to VEGF-A-induced angiogenesis. J Biol Chem. 2007;282:15187-96.

92. Staniszewska I, Zaveri S, Del Valle L, Oliva I, Rothman VL, Croul SE, et al. Interaction of $\alpha 9 \beta 1$ integrin with thrombospondin-1 promotes angiogenesis. Circ Res. 2007;100:1308-16.

93. Mishima K, Watabe T, Saito A, Yoshimatsu Y, Imaizumi N, Masui S, et al. Prox1 induces lymphatic endothelial differentiation via integrin a9 and other signaling cascades. Mol Biol Cell. 2007;18:1421-9.

94. Vlahakis NE, Young BA, Atakilit A, Sheppard D. The lymphangiogenic vascular endothelial growth factors VEGF-C and $-\mathrm{D}$ are ligands for the integrin a9 $\beta 1$. J Biol Chem. 2005;280:4544-52.

95. Huang XZ, Wu JF, Ferrando R, Lee JH, Wang YL, Farese RVJr., et al. Fatal bilateral chylothorax in mice lacking the integrin a9ß1. Mol Cell Biol. 2000;20:5208-15.

96. Brooks PC, Clark RA, Cheresh DA. Requirement of vascular integrin av $\beta 3$ for angiogenesis. Science. 1994;264:569-71.

97. Cheresh DA. Human endothelial cells synthesize and express an Arg-Gly-Asp-directed adhesion receptor involved in attachment to fibrinogen and von Willebrand factor. Proc Natl Acad Sci U S A. 1987;84:6471-5.

98. Brooks PC, Montgomery AM, Rosenfeld M, Reisfeld RA, Hu T, Klier $G$, et al. Integrin $\operatorname{av} \beta 3$ antagonists promote tumor regression by inducing apoptosis of angiogenic blood vessels. Cell. 1994;79:1157-64.

99. Friedlander M, Theesfeld CL, Sugita M, Fruttiger M, Thomas MA, Chang $S$, et al. Involvement of integrins av $\beta 3$ and av $\beta 5$ in ocular neovascular diseases. Proc Natl Acad Sci U S A. 1996;93:9764-9. 
100.Stupack DG, Puente XS, Boutsaboualoy S, Storgard CM, Cheresh DA. Apoptosis of adherent cells by recruitment of caspase-8 to unligated integrins. J Cell Biol. 2001;155:459-70.

101.Stromblad S, Becker JC, Yebra M, Brooks PC, Cheresh DA. Suppression of p53 activity and p21WAF1/CIP1 expression by vascular cell integrin av $\beta 3$ during angiogenesis. J Clin Invest. 1996;98:426-33.

102.Eliceiri BP, Klemke R, Stromblad S, Cheresh DA. Integrin av 33 requirement for sustained mitogen-activated protein kinase activity during angiogenesis. J Cell Biol. 1998;140:1255-63.

103.Gutheil JC, Campbell TN, Pierce PR, Watkins JD, Huse WD, Bodkin DJ, et al. Targeted antiangiogenic therapy for cancer using Vitaxin: a humanized monoclonal antibody to the integrin av 33 . Clin Cancer Res. 2000;6:3056-61.

104.Nabors LB, Mikkelsen T, Rosenfeld SS, Hochberg F, Akella NS, Fisher JD, et al. Phase I and correlative biology study of cilengitide in patients with recurrent malignant glioma. J Clin Oncol. 2007;25:1651-7.

105.Stupp R, Ruegg C. Integrin inhibitors reaching the clinic. J Clin Oncol. 2007;25:1637-8.

106. Reynolds AR, Hart IR, Watson AR, Welti JC, Silva RG, Robinson SD, et al. Stimulation of tumor growth and angiogenesis by low concentrations of RGD-mimetic integrin inhibitors. Nat Med. 2009;15:392-400.

107.Bader BL, Rayburn H, Crowley D, Hynes RO. Extensive vasculogenesis, angiogenesis, and organogenesis precede lethality in mice lacking all av integrins. Cell. 1998;95:507-19.

108.Lacy-Hulbert A, Smith AM, Tissire H, Barry M, Crowley D, Bronson RT, et al. Ulcerative colitis and autoimmunity induced by loss of myeloid av integrins. Proc Natl Acad Sci U S A. 2007;104:15823-8.

109. Reynolds LE, Wyder L, Lively JC, Taverna D, Robinson SD, Huang $X$, et al. Enhanced pathological angiogenesis in mice lacking $\beta 3$ integrin or $\beta 3$ and $\beta 5$ integrins. Nat Med. 2002;8:27-34

110.Hodivala-Dilke KM, McHugh KP, Tsakiris DA, Rayburn H, Crowley D, Ullman-Cullere $\mathrm{M}$, et al. $\beta 3$-integrin-deficient mice are a model for Glanzmann thrombasthenia showing placental defects and reduced survival. J Clin Invest. 1999;103:229-38.

111.Weis SM, Lindquist JN, Barnes LA, Lutu-Fuga KM, Cui J, Wood $\mathrm{MR}$, et al. Cooperation between VEGF and $\beta 3$ integrin during cardiac vascular development. Blood. 2007;109:1962-70.

112. Mahabeleshwar GH, Feng W, Phillips DR, Byzova TV. Integrin signaling is critical for pathological angiogenesis. J Exp Med. 2006;203:2495-507.

113.Hodivala-Dilke KM, Reynolds AR, Reynolds LE. Integrins in angiogenesis: multitalented molecules in a balancing act. Cell Tissue Res. 2003;314:131-44.

114.Avraamides CJ, Garmy-Susini B, Varner JA. Integrins in angiogenesis and lymphangiogenesis. Nat Rev Cancer. 2008;8:604-17.

115.Friedlander M, Brooks PC, Shaffer RW, Kincaid CM, Varner JA, Cheresh DA. Definition of two angiogenic pathways by distinct alpha $v$ integrins. Science. 1995;270:1500-2.

116.Alon T, Hemo I, Itin A, Pe'er J, Stone J, Keshet E. Vascular endothelial growth factor acts as a survival factor for newly formed retinal vessels and has implications for retinopathy of prematurity. Nat Med. 1995;1:1024-8.

117.Criscuoli ML, Nguyen M, Eliceiri BP. Tumor metastasis but not tumor growth is dependent on Src-mediated vascular permeability. Blood. 2005;105:1508-14.

118.Huang X, Griffiths M, Wu J, Farese RVJr., Sheppard D. Normal development, wound healing, and adenovirus susceptibility in 35 -deficient mice. Mol Cell Biol. 2000;20:755-9.

119.Breuss JM, Gillett N, Lu L, Sheppard D, Pytela R. Restricted distribution of integrin $\beta 6$ mRNA in primate epithelial tissues. J Histochem Cytochem. 1993;41:1521-7.
120.Breuss JM, Gallo J, DeLisser HM, Klimanskaya IV, Folkesson HG, Pittet JF, et al. Expression of the $\beta 6$ integrin subunit in development, neoplasia and tissue repair suggests a role in epithelial remodeling. J Cell Sci. 1995;108 ( Pt 6):2241-51.

121.Hakkinen L, Hildebrand HC, Berndt A, Kosmehl H, Larjava H. Immunolocalization of tenascin- $\mathrm{C}$, a9 integrin subunit, and av $\beta 6$ integrin during wound healing in human oral mucosa. J Histochem Cytochem. 2000;48:985-98.

122.Huang $\mathrm{X}, \mathrm{Wu} \mathrm{J}$, Spong S, Sheppard D. The integrin av $\beta 6$ is critical for keratinocyte migration on both its known ligand, fibronectin, and on vitronectin. J Cell Sci. 1998;111 ( Pt 15):2189-95.

123.Thomas GJ, Poomsawat S, Lewis MP, Hart IR, Speight PM, Marshall JF. av $\beta 6$ Integrin upregulates matrix metalloproteinase 9 and promotes migration of normal oral keratinocytes. J Invest Dermatol. 2001;116:898-904.

124.Thomas GJ, Hart IR, Speight PM, Marshall JF. Binding of TGF- $\beta 1$ latency-associated peptide (LAP) to av $\beta 6$ integrin modulates behaviour of squamous carcinoma cells. Br J Cancer. 2002;87:859-67.

125.Zambruno G, Marchisio PC, Marconi A, Vaschieri C, Melchiori A, Giannetti A, et al. Transforming growth factor- $\beta 1$ modulates $\beta 1$ and $\beta 5$ integrin receptors and induces the de novo expression of the av $\beta 6$ heterodimer in normal human keratinocytes: implications for wound healing. J Cell Biol. 1995;129:853-65.

126.Koivisto L, Larjava K, Hakkinen L, Uitto VJ, Heino J, Larjava H. Different integrins mediate cell spreading, haptotaxis and lateral migration of $\mathrm{HaCaT}$ keratinocytes on fibronectin. Cell Adhes Commun. 1999;7:245-57.

127.Kawashima A, Tsugawa S, Boku A, Kobayashi M, Minamoto T, Nakanishi I, et al. Expression of av integrin family in gastric carcinomas: increased av $\beta 6$ is associated with lymph node metastasis. Pathol Res Pract. 2003;199:57-64.

128.Sipos B, Hahn D, Carceller A, Piulats J, Hedderich J, Kalthoff H, et al. Immunohistochemical screening for $\beta 6$-integrin subunit expression in adenocarcinomas using a novel monoclonal antibody reveals strong up-regulation in pancreatic ductal adenocarcinomas in vivo and in vitro. Histopathology. 2004:45:226-36

129.Jones J, Watt FM, Speight PM. Changes in the expression of av integrins in oral squamous cell carcinomas. J Oral Pathol Med. 1997;26:63-8.

130.Ahmed N, Riley C, Rice GE, Quinn MA, Baker MS. av $\beta 6$ integrin-A marker for the malignant potential of epithelial ovarian cancer. J Histochem Cytochem. 2002;50:1371-80.

131.Arihiro K, Kaneko M, Fujii S, Inai K, Yokosaki Y. Significance of a9 $\beta 1$ and $\alpha v \beta 6$ integrin expression in breast carcinoma. Breast Cancer. 2000;7:19-26.

132.Bates RC, Bellovin DI, Brown C, Maynard E, Wu B, Kawakatsu $\mathrm{H}$, et al. Transcriptional activation of integrin $\beta 6$ during the epithelial-mesenchymal transition defines a novel prognostic indicator of aggressive colon carcinoma. J Clin Invest. 2005;115:339-47.

133.Agrez M, Chen A, Cone RI, Pytela R, Sheppard D. The av $\beta 6$ integrin promotes proliferation of colon carcinoma cells through a unique region of the $\beta 6$ cytoplasmic domain. J Cell Biol. 1994;127:547-56.

134.Morgan MR, Thomas GJ, Russell A, Hart IR, Marshall JF. The integrin cytoplasmic-tail motif EKQKVDLSTDC is sufficient to promote tumor cell invasion mediated by matrix metalloproteinase (MMP)-2 or MMP-9. J Biol Chem. 2004;279:26533-9.

135.Niu J, Dorahy DJ, Gu X, Scott RJ, Draganic B, Ahmed N, et al. Integrin expression in colon cancer cells is regulated by the cytoplasmic domain of the $\beta 6$ integrin subunit. Int J Cancer. 2002;99:529-37. 
136.Ahmed N, Pansino F, Clyde R, Murthi P, Quinn MA, Rice GE, et al. Overexpression of av $\beta 6$ integrin in serous epithelial ovarian cancer regulates extracellular matrix degradation via the plasminogen activation cascade. Carcinogenesis. 2002;23:237-44.

137.Munger JS, Huang X, Kawakatsu H, Griffiths MJ, Dalton SL, $\mathrm{Wu}$ J, et al. The integrin av $\beta 6$ binds and activates latent TGF $\beta 1$ : a mechanism for regulating pulmonary inflammation and fibrosis. Cell. 1999;96:319-28.

138.Hamidi S, Salo T, Kainulainen T, Epstein J, Lerner K, Larjava H. Expression of av $\beta 6$ integrin in oral leukoplakia. Br J Cancer. 2000;82:1433-40.

139.Thomas GJ, Nystrom ML, Marshall JF. av $\beta 6$ integrin in wound healing and cancer of the oral cavity. J Oral Pathol Med. 2006:35:1-10.

140.Falcioni R, Antonini A, Nistico P, Di Stefano S, Crescenzi M, Natali PG, et al. a6 $\beta 4$ and a $6 \beta 1$ integrins associate with ErbB-2 in human carcinoma cell lines. Exp Cell Res. 1997;236:76-85.

141.Hemler ME, Crouse C, Sonnenberg A. Association of the VLA a6 subunit with a novel protein. A possible alternative to the common VLA $\beta 1$ subunit on certain cell lines. J Biol Chem. 1989;264:6529-35.

142.Wilhelmsen K, Litjens SH, Sonnenberg A. Multiple functions of the integrin a $6 \beta 4$ in epidermal homeostasis and tumorigenesis. Mol Cell Biol. 2006;26:2877-86.

143.Dowling J, Yu QC, Fuchs E. $\beta 4$ integrin is required for hemidesmosome formation, cell adhesion and cell survival. J Cell Biol. 1996;134:559-72.

144.Geerts D, Fontao L, Nievers MG, Schaapveld RQ, Purkis PE, Wheeler GN, et al. Binding of integrin a $6 \beta 4$ to plectin prevents plectin association with F-actin but does not interfere with intermediate filament binding. J Cell Biol. 1999;147:417-34.

145.Koster J, Geerts D, Favre B, Borradori L, Sonnenberg A. Analysis of the interactions between BP180, BP230, plectin and the integrin a6 64 important for hemidesmosome assembly. J Cell Sci. 2003;116:387-99.

146.Sterk LM, Geuijen CA, Oomen LC, Calafat J, Janssen H, Sonnenberg A. The tetraspan molecule CD151, a novel constituent of hemidesmosomes, associates with the integrin a6ß4 and may regulate the spatial organization of hemidesmosomes. J Cell Biol. 2000;149:969-82.

147.Shaw LM, Rabinovitz I, Wang HH, Toker A, Mercurio AM. Activation of phosphoinositide $3-\mathrm{OH}$ kinase by the a6 34 integrin promotes carcinoma invasion. Cell. 1997;91:949-60..

148.Mariotti A, Kedeshian PA, Dans M, Curatola AM, Gagnoux-Palacios L, Giancotti FG. EGF-R signaling through Fyn kinase disrupts the function of integrin a6 $\beta 4$ at hemidesmosomes: role in epithelial cell migration and carcinoma invasion. J Cell Biol. 2001;155:447-58.

149. Yoon CS, Kim KD, Park SN, Cheong SW. a6 Integrin is the main receptor of human papillomavirus type 16 VLP. Biochem Biophys Res Commun. 2001;283:668-73.

150.Springer TA. Traffic signals for lymphocyte recirculation and leukocyte emigration: the multistep paradigm. Cell. 1994;76:301-14

151.Rose DM, Alon R, Ginsberg MH. Integrin modulation and signaling in leukocyte adhesion and migration. Immunol Rev. 2007;218:126-34.

152.Luster AD, Alon R, von Andrian UH. Immune cell migration in inflammation: present and future therapeutic targets. Nat Immunol. 2005;6:1182-90.

153.Anderson DC, Springer TA. Leukocyte adhesion deficiency: an inherited defect in the Mac-1, LFA-1, and p150,95 glycoproteins. Annu Rev Med. 1987;38:175-94.

154.Carman CV, Springer TA. Integrin avidity regulation: are changes in affinity and conformation underemphasized? Curr Opin Cell Biol. 2003;15:547-56.
155.Alon R, Feigelson S. From rolling to arrest on blood vessels: leukocyte tap dancing on endothelial integrin ligands and chemokines at sub-second contacts. Semin Immunol. 2002;14:93-104.

156.Alon R, Dustin ML. Force as a facilitator of integrin conformational changes during leukocyte arrest on blood vessels and antigen-presenting cells. Immunity. 2007;26:17-27.

157.Katagiri K, Imamura M, Kinashi T. Spatiotemporal regulation of the kinase Mst1 by binding protein RAPL is critical for lymphocyte polarity and adhesion. Nat Immunol. 2006;7:919-28.

158.Kinashi T. Intracellular signalling controlling integrin activation in lymphocytes. Nat Rev Immunol. 2005;5:546-59.

159.Borriello G, Prosperini L, Luchetti A, Pozzilli C. Natalizumab treatment in pediatric multiple sclerosis: a case report. Eur J Paediatr Neurol. 2009;13:67-71.

160.Lebwohl M, Tyring SK, Hamilton TK, Toth D, Glazer S, Tawfik $\mathrm{NH}$, et al. A novel targeted T-cell modulator, efalizumab, for plaque psoriasis. N Engl J Med. 2003;349:2004-13.

161.Chavakis T, Hussain M, Kanse SM, Peters G, Bretzel RG, Flock JI, et al. Staphylococcus aureus extracellular adherence protein serves as anti-inflammatory factor by inhibiting the recruitment of host leukocytes. Nat Med. 2002;8:687-93.

162.Koivunen E, Ranta TM, Annila A, Taube S, Uppala A, Jokinen $\mathrm{M}$, et al. Inhibition of $\beta 2$ integrin-mediated leukocyte cell adhesion by leucine-leucine-glycine motif-containing peptides. J Cell Biol. 2001;153:905-16.

163.Stefanidakis M, Ruohtula T, Borregaard N, Gahmberg CG, Koivunen E. Intracellular and cell surface localization of a complex between $\mathrm{aM} \beta 2$ integrin and promatrix metalloproteinase-9 progelatinase in neutrophils. J Immunol. 2004;172:7060-8.

164.Choi EY, Chavakis E, Czabanka MA, Langer HF, Fraemohs L, Economopoulou $\mathrm{M}$, et al. Del-1, an endogenous leukocyte-endothelial adhesion inhibitor, limits inflammatory cell recruitment. Science. 2008;322:1101-4.

165.Mousa SA. Anti-integrin as novel drug-discovery targets: potential therapeutic and diagnostic implications. Curr Opin Chem Biol. 2002;6:534-41.

166.Mullamitha SA, Ton NC, Parker GJ, Jackson A, Julyan PJ, Roberts $C$, et al. Phase I evaluation of a fully human anti-av integrin monoclonal antibody (CNTO 95) in patients with advanced solid tumors. Clin Cancer Res. 2007;13:2128-35.

167.Mitjans F, Meyer T, Fittschen C, Goodman S, Jonczyk A, Marshall JF, et al. In vivo therapy of malignant melanoma by means of antagonists of av integrins. Int $\mathrm{J}$ Cancer. 2000;87:716-23.

168.O'Connor P. Natalizumab and the role of a4-integrin antagonism in the treatment of multiple sclerosis. Expert Opin Biol Ther. 2007;7:123-36.

169.Dechantsreiter MA, Planker E, Matha B, Lohof E, Holzemann G, Jonczyk A, et al. N-Methylated cyclic RGD peptides as highly active and selective av $\beta 3$ integrin antagonists. J Med Chem. 1999;42:3033-40.

170.Belvisi L, Bernardi A, Colombo M, Manzoni L, Potenza D, Scolastico C, et al. Targeting integrins: insights into structure and activity of cyclic RGD pentapeptide mimics containing azabicycloalkane amino acids. Bioorg Med Chem. 2006;14:169-80.

171.Kumar CC, Malkowski M, Yin Z, Tanghetti E, Yaremko B, Nechuta T, et al. Inhibition of angiogenesis and tumor growth by $\mathrm{SCH} 221153$, a dual $\alpha v \beta 3$ and $\operatorname{av} \beta 5$ integrin receptor antagonist. Cancer Res. 2001;61:2232-8.

172.Byron A, Humphries JD, Askari JA, Craig SE, Mould AP, Humphries MJ. Anti-integrin monoclonal antibodies. J Cell Sci. 2009;122:4009-11. 
173.Cai W, Zhang X, Wu Y, Chen X. A thiol-reactive ${ }^{18}$ F-labeling agent, $\quad \mathrm{N}-\left[2-\left(4-{ }^{18} \mathrm{~F}-\right.\right.$ fluorobenzamido)ethyl]maleimide, and synthesis of RGD peptide-based tracer for PET imaging of av $\beta 3$ integrin expression. J Nucl Med. 2006;47:1172-80.

174.Li ZB, Cai W, Cao Q, Chen K, Wu Z, He L, et al. ${ }^{64} \mathrm{Cu}$-labeled tetrameric and octameric RGD peptides for small-animal PET of tumor av $\beta 3$ integrin expression. J Nucl Med. 2007;48:1162-71.

175.Beer AJ, Haubner R, Sarbia M, Goebel M, Luderschmidt S, Grosu AL, et al. Positron emission tomography using $\left[{ }^{18} \mathrm{~F}\right]$ Galacto-RGD identifies the level of integrin $\alpha(v) \beta 3$ expression in man. Clin Cancer Res. 2006;12:3942-9.

176.Leong-Poi H, Christiansen J, Klibanov AL, Kaul S, Lindner JR. Noninvasive assessment of angiogenesis by ultrasound and microbubbles targeted to av-integrins. Circulation. 2003;107:455-60.

177.Wang H, Chen K, Cai W, Li Z, He L, Kashefi A, et al. Integrin-targeted imaging and therapy with RGD4C-TNF fusion protein. Mol Cancer Ther. 2008;7:1044-53.

178.Somanath PR, Malinin NL, Byzova TV. Cooperation between integrin $a v \beta 3$ and VEGFR2 in angiogenesis. Angiogenesis. 2009;12:177-85.

179.Wang SE, Xiang B, Zent R, Quaranta V, Pozzi A, Arteaga CL. Transforming growth factor $\beta$ induces clustering of HER2 and integrins by activating Src-focal adhesion kinase and receptor association to the cytoskeleton. Cancer Res. 2009;69:475-82.

180.Morozevich G, Kozlova N, Cheglakov I, Ushakova N, Berman A. Integrin a5 31 controls invasion of human breast carcinoma cells by direct and indirect modulation of MMP-2 collagenase activity. Cell Cycle. 2009;8:2219-25.

181.Maupas-Schwalm F, Bedel A, Auge N, Grazide MH, Mucher E, Thiers JC, et al. Integrin av $\beta 3$, metalloproteinases, and sphingomyelinase-2 mediate urokinase mitogenic effect. Cell Signal. 2009;21:1925-34.

182. Orr AW, Ginsberg MH, Shattil SJ, Deckmyn H, Schwartz MA. Matrix-specific suppression of integrin activation in shear stress signaling. Mol Biol Cell. 2006;17:4686-97.

183.Diaz-Gonzalez F, Forsyth J, Steiner B, Ginsberg MH. Trans-dominant inhibition of integrin function. Mol Biol Cell. 1996;7:1939-51.

184.Dibya D, Sander S, Smith EA. Identifying cytoplasmic proteins that affect receptor clustering using fluorescence resonance energy transfer and RNA interference. Anal Bioanal Chem. 2009; 395(7):2303-11.

185.Chigaev A, Buranda T, Dwyer DC, Prossnitz ER, Sklar LA. FRET detection of cellular a4-integrin conformational activation. Biophys J. 2003;85:3951-62.

186. Chen X. Multimodality imaging of tumor integrin av $\beta 3$ expression. Mini Rev Med Chem. 2006;6:227-34. 